\title{
Erg Potassium Currents of Neonatal Mouse Purkinje Cells Exhibit Fast Gating Kinetics and Are Inhibited by mGluR1 Activation
}

\author{
Dragos Niculescu, Wiebke Hirdes, Sönke Hornig, Olaf Pongs, and Jürgen R. Schwarz \\ Institute for Molecular Neurogenetics, Center for Molecular Neurobiology (ZMNH), University of Hamburg, D-20251 Hamburg, Germany
}

We investigated the subthreshold properties of an erg (ether-à-go-go-related gene) $\mathrm{K}^{+}$current in Purkinje cells of neonatal mice. Action potentials recorded from Purkinje cells in cerebellar slices exhibited a decreased threshold potential and increased frequency of spontaneous and repetitive activity following application of the specific erg channel blocker E-4031. Accommodation was absent before and after drug application. The erg current of these Purkinje cells activated at membrane potentials near $-60 \mathrm{mV}$ and exhibited fast gating kinetics. The functional importance of fast gating subthreshold erg channels in Purkinje cells was corroborated by comparing the results of action potential clamp experiments with ergla, erg1b, erg2, and erg3 currents heterologously expressed in HEK cells. Computer simulations based on a NEURON model of Purkinje cells only reproduced the effects of the native erg current when an erg channel conductance like that of erg3 was included. Experiments with subunit-sensitive toxins (BeKm-1, APETx1) indicated that erg channels in Purkinje cells are presumably mediated by heteromeric erg1/erg3 or modified erg1 channels. Following mGluR1 activation, the native erg current was reduced by $\sim 70 \%$, brought about by reduction of the maximal erg current and a shift of the activation curve to more positive potentials. The Purkinje cell erg current contributed to the sustained current component of the biphasic mGluR1 response. Activation of mGluR1 by the agonist 3,4-dihydroxyphenylglycol increased Purkinje cell excitability, similar to that induced by E-4031. The results indicated that erg currents can be modulated and may contribute to the mGluR1-induced plasticity changes in Purkinje cells.

\section{Introduction}

Electrical activity of Purkinje cells provides the sole output of the cerebellar cortex and is essential for the control of coordinated movements (Ito, 2006). Cerebellar malfunction leads to poor balance, cerebellar ataxia, and impaired performance of rapid and alternating movements (Llinás et al., 2004). One of the ionic currents contributing to the intrinsic activity of Purkinje cells (Raman and Bean, 1999; Khaliq et al., 2003) is mediated by erg (ether-à-go-go-related gene) channels (Sacco et al., 2003). In adult mice, pharmacological blockage of erg currents increased the frequency of action potential firing in Purkinje cells and reduced their pronounced accommodation (Sacco et al., 2003). Erg

\footnotetext{
Received Nov. 30, 2012; revised Sept. 5, 2013; accepted Sept. 10, 2013.

Author contributions: D.N., W.H., S.H., O.P., and J.R.S. designed research; D.N., W.H., S.H., and J.R.S. performed research; D.N., W.H., S.H., and J.R.S. analyzed data; O.P. and J.R.S. wrote the paper.

This work was supported by the Deutsche Forschungsgemeinschaft (Schw292/14-1, Schw292/16-1). We thank Dr. N.T. Carnevale (Yale University), Dr. H.-M. Ziethen, and L. Glau (ZMNH) for help with NEURON; Dr. S. HoffmeisterUllerich (Center for Molecular Neurobiology) for help with the qPCR; P. Breiden for help with the cell culture and constructing HEK 293 cells stably transfected with erg1, erg2, or erg3 channels; Dr. M. Lazdunski and Dr. S. Diochot (Valbonne, France) for their gift of the sea anemone toxin APETx1; and Dr. M. Kneussel for his generous hospitality. Authors declare no competing financial interests.

Correspondence should be addressed to Dr. Jürgen R. Schwarz, Institute for Molecular Neurogenetics, Center for Molecular Neurobiology, University Hospital Hamburg-Eppendorf, Falkenried 94, D-20251 Hamburg, Germany. E-mail:schwarz@uke.uni-hamburg.de.

D. Niculescu's present address is Synapse and Network Development, Netherlands Institute for Neuroscience, Meibergdreef 47, 1105 BA Amsterdam, The Netherlands.

0. Pong's present address is Saarland University, Institute of Physiology, Building 59, 66421 Homburg, Germany. DOI:10.1523/JNEUROSCI.5523-12.2013

Copyright $\odot 2013$ the authors $\quad 0270-6474 / 13 / 3316729-12 \$ 15.00 / 0$
}

currents with similar functions have been described in neurons of the spinal cord (Furlan et al., 2007), brainstem (Hirdes et al., 2005; Pessia et al., 2008; Hardman and Forsythe, 2009), olfactory bulb (Hirdes et al., 2009), and vomero-nasal organ (Hagendorf et al., 2009).

Three genes (erg1, erg2, erg3) encoding erg channel subunits have been cloned. In contrast to other voltage-gated potassium channels, erg channels are equipped with "inversed" gating kinetics, i.e., they inactivate faster than they activate, transforming them functionally into inwardly rectifying $\mathrm{K}^{+}$channels (Shibasaki, 1987). In the heart, erg channel expression is restricted to ergla and its isoform erglb. Cardiac erg channels mediate the rapidly activating delayed rectifier $\left(I_{\mathrm{Kr}}\right)$, which contributes to repolarization of the cardiac action potential (Curran et al., 1995). Dysfunction of cardiac erg channels induces a long QT syndrome (LQT-2; Sanguinetti and Tristani-Firouzi, 2006). In the brain, the three erg channels (as well as their isoforms) are expressed (Saganich et al., 2001; Guasti et al., 2005; Hagendorf et al., 2009) and may also be coexpressed in single neurons (Hirdes et al., 2005). The time-dependent and voltage-dependent properties of homomeric and heteromeric erg channels that can be formed have been studied in heterologous expression systems (Shi et al., 1997; Wimmers et al., 2002; Sturm et al., 2005). However, although the functional importance of erg currents for the control of neuronal excitability is widely appreciated, the function of each of the different neuronal erg channels expressed in a particular neuron is still elusive.

In the present study, we first characterized the subthreshold properties of the erg current in Purkinje cells of neonatal mice 
Table 1. Extracellular solutions (ACSF) ${ }^{a}$

\begin{tabular}{lcccccc}
\hline & $\begin{array}{l}\text { Standard } \\
\text { solution }\end{array}$ & $\begin{array}{l}\text { Cutting } \\
\text { solution }\end{array}$ & $\begin{array}{l}\text { Current clamp, } \\
\text { on-cell }\end{array}$ & $\begin{array}{l}\text { Action potential } \\
\text { clamp }\end{array}$ & $8 \mathrm{~mm} \mathrm{~K}^{+}$ & $40 \mathrm{~mm} \mathrm{~K}^{+}$ \\
\hline $\mathrm{KCl}$ & 2.5 & 2.5 & 5 & 5 & 8 & 40 \\
$\mathrm{NaCl}$ & 125 & 125 & 122.5 & 122.5 & 119.5 & 87.5 \\
$\mathrm{MgCl}_{2}$ & 1 & 3 & 1 & 2 & 3 & 3 \\
$\mathrm{CaCl}_{2}$ & 2 & 0 & 2 & 1 & 0 & 0 \\
$\mathrm{NaHCO}_{3}$ & 26 & 26 & 26 & 26 & 26 & 26 \\
$\mathrm{NaH}_{2} \mathrm{PO}_{4}$ & 1.25 & 1.25 & 1.25 & 1.25 & 1.25 & 1.25 \\
$\mathrm{Glucose}$ & 20 & 20 & 20 & 20 & 20 & 20 \\
$\mathrm{pH}$ (carbogen) & 7.4 & 7.4 & 7.4 & 7.4 & 7.4 & 7.4 \\
\hline
\end{tabular}

${ }^{a}$ The table contains the solutions used in the slice experiments (concentrations given in $\mathrm{mm}$ ). For composition of solutions used in experiments with cultured cells, see Material and Methods.

and tried to determine which of the four erg channel subunits (erg1a, erg1b, erg2, erg3) contribute to channel formation. To avoid space clamp problems, we restricted the experiments to Purkinje cells of neonatal mice [postnatal day (P) 5-P10], which are experimentally more suitable than Purkinje cells of adult mice. The native erg current exhibits fast gating kinetics and activates at negative membrane potentials. The native erg channels are presumably heteromeric erg1/erg 3 channels or composed of modified erg1 subunits. This suggestion was corroborated by experiments with subunit-sensitive toxins (BeKm-1, APETx1), action potential clamp experiments, and computer simulations. The decrease of cerebellar erg3 protein expression during development by $50 \%$ supported its possible involvement in erg channel formation in Purkinje cells of neonatal mice. Second, we show that mGluR1 activation inhibits erg current and that this inhibition increases Purkinje cell excitability.

\section{Materials and Methods}

Acute slice preparation. Cerebellar slices were prepared from P5-P10 C57BL/6 male mice. In accordance with institutional guidelines of the University of Hamburg, animals were decapitated and the brain was quickly removed and immersed in ice-cold carbogenated $\left(95 \% \mathrm{O}_{2}, 5 \%\right.$ $\mathrm{CO}_{2}$ ) modified standard artificial CSF (ACSF) containing $3 \mathrm{~mm} \mathrm{MgCl}_{2}$ and no $\mathrm{CaCl}_{2}$. The brain was cut in the midsagittal plane and the two halves were glued with cyanoacrylate on the cutting plate of a vibratome (Leica VT1200S). Parasagittal slices of $200 \mu \mathrm{m}$ were cut and subsequently incubated in standard ACSF at $35^{\circ} \mathrm{C}$ for $1 \mathrm{~h}$. The recordings were made within $8 \mathrm{~h}$ after incubation.

Heterologous expression. The cDNAs for rat erg channel subunits, $\operatorname{erg} 1 a, \operatorname{erg} 1 b, \operatorname{erg} 2$, and $\operatorname{erg} 3$, were subcloned into the pcDNA3 vector (Invitrogen) and transiently transfected into HEK293 cells cultivated in DMEM/Ham's F12 medium (PAA Laboratories) with $1 \%$ penicilline/ streptomycine/L-glutamine and $10 \% \mathrm{FBS}$ at $37^{\circ} \mathrm{C}$ in a water-saturated atmosphere of $95 \%$ air and $5 \% \mathrm{CO}_{2}$. The same protocol was used for erg1/erg3 concatemers (Wimmers et al., 2002). For transfection, cells were placed on poly-L-lysine-coated glass coverslips and used within 1-3 d. Transfection was performed according to the manufacturers instructions with lipofectamine (Invitrogen), $1 \mu \mathrm{g}$ of channel cDNA, and $0.6 \mu \mathrm{g}$ of pcDNA3/mCherry (kindly provided by Dr. U. Boehm, Center for Molecular Neurobiology, University of Hamburg) in Optimem (Invitrogen). Transfected cells were fluorescent when stimulated at $540 \mathrm{~nm}$. For stable transfection, cDNA of erg channels was linearized with MeuI (Fermentas) and transfected into HEK293 cells with calcium phosphate. Stable expression was achieved by using geneticin (Sigma-Aldrich).

Solutions and chemicals. Extracellular solutions (ACSF) used in the acute slice experiments are summarized in Table 1. The $\mathrm{pH}$ was adjusted for all ACSF solutions to 7.4 with carbogen during the experiment. The Ringer's solution contained the following: $135 \mathrm{~mm} \mathrm{NaCl}, 5 \mathrm{~mm} \mathrm{KCl}, 1 \mathrm{~mm}$ $\mathrm{CaCl}_{2}, 2 \mathrm{~mm} \mathrm{MgCl}_{2}, 10 \mathrm{~mm}$ HEPES, $5 \mathrm{~mm}$ glucose, $\mathrm{pH}$ adjusted to 7.4 with $\mathrm{NaOH}$. Two pipette solutions were used. The K-methanesulfonate solution contained the following: $123 \mathrm{mM} \mathrm{K}^{+}$-methanesulfonate, $9 \mathrm{mM}$ $\mathrm{NaCl}, 1.8 \mathrm{~mm} \mathrm{MgCl}_{2}, 0.9 \mathrm{~mm}$ EGTA, $9 \mathrm{~mm}$ HEPES, $14 \mathrm{~mm} \mathrm{Na}_{2}-$ phosphocreatine, $4 \mathrm{~mm}$ MgATP, $0.3 \mathrm{~mm} \mathrm{Na} \mathrm{N}_{3} \mathrm{GTP}$, pH adjusted to 7.3 with $\mathrm{KOH}$. This solution was used in the whole-cell configuration (Jackson and Bean, 2007). The $\mathrm{K}^{+}$-gluconate solution contained the following: $140 \mathrm{~mm} \mathrm{~K}^{+}$-gluconate, $4 \mathrm{~mm} \mathrm{MgCl}_{2}, 0.5$ mм EGTA, 10 mM HEPES, $4 \mathrm{~mm} \mathrm{Na}_{2} \mathrm{ATP}, 0.4 \mathrm{~mm} \mathrm{Na}_{3} \mathrm{GTP}$, pH adjusted to 7.3 with $\mathrm{KOH}$. This solution was used in the on-cell configuration (Sacco et al., 2003). Liquid junction potentials were not corrected. To isolate erg currents, the application of $1 \mu \mathrm{M}$ of the antiarrhythmic drug E-4031 (Eisai) was sufficient to achieve a complete block. To see the rapid effect of erg channel blockage on the firing activity of the neurons, $5 \mu \mathrm{M}$ E-4031 was used. To eliminate synaptic activity, synaptic blockers were added to the ACSF to block NMDA (AP-5, $50 \mu \mathrm{M})$, AMPA (CNQX, $10 \mu \mathrm{M}$ ), and $\mathrm{GABA}_{\mathrm{A}}$ receptors (bicuculline, $20 \mu \mathrm{M}$ ). As a mGluR1 agonist, (S)-3,5-3,4-dihydroxyphenylglycol (DHPG; $50 \mu \mathrm{M}$ ) was used. Synaptic blockers and DHPG were purchased from Ascent Scientific. All experiments were done at room temperature $\left(22-25^{\circ} \mathrm{C}\right)$. Chemicals were purchased from Sigma-Aldrich. The scorpion toxin BeKm-1 was purchased from Alomone Labs. The sea anemone toxin APETx1 was a kind gift from Dr. M. Lazdunski and Dr. S. Diochot (Valbonne, France).

Electrophysiology. Purkinje cells and transfected HEK293 cells were patch-clamped under a water-immersed $40 \times$ objective of a Zeiss Axioskop 2 FS Plus microscope. Purkinje cells were chosen for recordings only if their dendritic initial segment was visible under infrared differential interference contrast optics. Borosilicate glass capillaries (GC150F-10, Harvard Apparatus) were pulled (Flaming/Brown micropipette puller, Model P-97, Sutter Instrument) and had a resistance of 3-5 M $\Omega$ when filled with internal solutions. Membrane currents and action potentials were recorded using an EPC9 amplifier (HEKA Elektronik). Only recordings with an access resistance $<30 \mathrm{M} \Omega$ were evaluated. Slices were perfused continuously $(1-1.5 \mathrm{ml} / \mathrm{min})$ with carbogenated ACSF. Data were analyzed using PulseFit (HEKA), Igor Pro 6.03 (Wavemetrics), and Excel (Microsoft). Averaged values are given as mean \pm SEM. Paired and unpaired two-tailed $t$ tests were performed to determine the level of statistical difference.

Quantitative PCR. Erg subunit expression was quantitatively investigated in cerebella of neonatal (P6) and adult (7-week-old) mice. The procedure was performed as described previously (Hirdes et al., 2009): RNA was isolated using TRIzol reagent (Invitrogen). One microgram of total RNA was used for oligo (dT) primed reverse transcription using RevertAid H Minus First Strand cDNA Synthesis Kit (Fermentas), according to standard protocols. cDNAs were amplified in a $20 \mu \mathrm{l}$ reaction with total RNA ( $11 \mu \mathrm{l}), 1 \mu \mathrm{l}$ of Random Primers (Fermentas), $1 \mu \mathrm{l}$ of (20 U) RiboLock RNase Inhibitor (Fermentas), $4 \mu$ l of $5 \times$ First Strand Buffer, $2 \mu \mathrm{l}$ of $1 \mathrm{~mm}$ deoxyribonucleotide triphosphates, and $1 \mu \mathrm{l}$ of $200 \mathrm{U}$ RevertAid H Minus Reverse Transcriptase (Fermentas). cDNAs were stored at $-20^{\circ} \mathrm{C}$. Quantitative PCR (qPCR) was performed with the SYBR GreenER SuperMix kit premixed with Rox reference dye (Invitrogen) in a volume of $20 \mu \mathrm{l}$ containing $2 \mu \mathrm{l}$ of cDNA ( $~ 20 \mathrm{ng}), 2 \mu \mathrm{l}$ of forward and reverse primer $(0.5 \mu \mathrm{M}), 10 \mu \mathrm{l}$ of SYBR Green, and $6 \mu \mathrm{l}$ of $\mathrm{H}_{2} \mathrm{O}$. All PCRs were performed in 96-well plates using an ABI Prism 7900 HT Sequence Detection System (Applied Biosystems). The thermal cycling conditions, equal for all primer pairs, comprised an initial step at $50^{\circ} \mathrm{C}$ for $2 \mathrm{~min}$ followed by a denaturating step at $95^{\circ} \mathrm{C}$ for $10 \mathrm{~min}$. The amplification stage consisted of 40 cycles at $95^{\circ} \mathrm{C}$ for $15 \mathrm{~s}$ and $60^{\circ} \mathrm{C}$ for $60 \mathrm{~s}$. Following this cycling condition, a melting curve analysis was performed by cooling the PCR product to $60^{\circ} \mathrm{C}$ for $15 \mathrm{~s}$ before gradual heating (ramp rate of $1^{\circ} \mathrm{C} / \mathrm{min}$ ) to $95^{\circ} \mathrm{C}$. Negative controls using water instead of cDNA as template and products generated without reverse transcriptase were included in every set of experiments. Analysis of the data was performed using Sequence Detection System (SDS) 2.4 software (Applied Biosystems). A correction was performed using a passive reference dye (Rox), which is present in the PCR master mix. Reactions with a cycle threshold value $>30$ or with any evidence of nonspecificity (low melting temperatures or multiple peaks in melting point analysis) were excluded from the analysis. The amounts of test sample (erg subunits) and reference genes [phosphoglycerate kinase 1 (pgk1) and transferrin receptor (Tfr)] were interpolated using a standard curve originated from mouse brain cDNA dilutions. The standard curves obtained with the pairs of primers listed below fulfilled the quality criteria given by the 
manufacturer (slope, $\geq 3.1$; correlation coefficient $r, \geq 0.99$ ) proving the efficiency of the primers. Expression levels of erg subunits were normalized to the two reference genes (pgk1, Tfr). For amplification, we used the following forward and reverse primer pairs (GenBank database, accession numbers in brackets): M-erg1a (NM_013569) nucleotides 425-660 (for detection of m-ergla and m-ergla-uso), 5'-CTCATGACACCAAC CACAGG-3' and 5'-GTTGTCCATGGCAGAAACCT-3'; $M$-erg $1 b$ (AF012869) nucleotides 11-200 (for detection of m-erglb and m-erglb-uso; 5'-CAACCGGGAAGGAGAGCAGGAC-3' and 5' -TTGAAGGGGCTGTA GTGGAG-3'; M-erg1a (NM_013569) nucleotides 2263-2452 and $M$-erg1b nucleotides 1607-1796 (AF012869; for detection of m-ergla and m-erglb without ergla-uso and erg1b-uso), 5'-GCGCTGGCTATGAAGTTCAA G-3' and 5' -CAGGACGGGCATATAGGTTCAGA-3'; M-erg2 (NM_001037712) nucleotides 1488-1716,5' -CATGCTCATTGGCTC ACTTATG-3' and 5'-GAAGCCTTTCAGCACCGCG-3'; M-erg3 (NM_133207) nucleotides 2882-3045, 5' -CAACCAGACTCCATGG TGAA-3' and 5'-GGCAGCTCTCTGAAGTCCTG-3'; pgk1 (NM_008828.2) nucleotides 54-267，5'-GGTCGTGATGAGGGTG GAC-3' and 5'-CAGCAGAGATTTGAGTTCAGCA-3'; Tfr (NM_011638) nucleotides 140-385, 5' -ATGCCGACAATAACATGA AGGC-3' and 5'-GGTCTGCCCAATATAAGCGAGA-3'.

Researchers have found that in humans HERGla-uso does not form functional erg channels after translation (Kupershmidt et al., 1998). Since it is not known whether ergla-uso exists in the mouse, we have chosen primer pairs for amplification of the different m-erg1 isoforms assuming a gene structure similar to that of HERG1a-uso and HERG1buso. One primer pair amplified $\mathrm{m}$-ergla and $\mathrm{m}$-erglb transcripts, a second primer pair m-ergla and m-ergla-uso, and a third primer pair $\mathrm{m}$-erg $1 \mathrm{~b}$ and $\mathrm{m}$-erglb-uso.

Simulation. To simulate the E-4031 effects on repetitive firing of action potentials, we used the Purkinje cell model by Khaliq, Gouwens, and Raman (KGR; Khaliq et al., 2003), written in the NEURON environment (Hines and Carnevale, 1997) and available from the NEURON homepage at https://senselab.med.yale.edu/modeldb/. The model incorporates eight ionic currents of mouse Purkinje cells (P14-P20): $\mathrm{Na}^{+}$current; three outwardly rectifying $\mathrm{K}^{+}$currents with fast, medium, or slow inactivation kinetics; $\mathrm{BK}$ current; P-type $\mathrm{Ca}^{2+}$ current; h current; and leak current. Simulations were done with data recorded at $22^{\circ} \mathrm{C}$. To increase the similarity between our current-clamp recordings in Purkinje cells and the computer simulations, we changed two conductances of the KGR model. First, the resurgent property of the $\mathrm{Na}^{+}$channel was removed since we did not observe repetitive after-potentials and high-frequency firing in our experiments. This change was done by reducing the rate constant that determines the formation of the blocked $\mathrm{Na}$ channel (rate constant $\varepsilon$ in the KGR model) from 1.75 to $10^{-12} \mathrm{~ms}^{-1}$ (Khaliq et al., 2003). In addition, $\mathrm{Na}^{+}$conductance was reduced from 0.015 to 0.010 $\mathrm{S} / \mathrm{cm}^{2}$. Second, the fast $\mathrm{K}^{+}$conductance was doubled (from 0.004 to $0.008 \mathrm{~S} / \mathrm{cm}^{2}$ ) to remove the spontaneous activity of the model. Rate constants of erg1a or erg3 activation and inactivation were determined from voltage-clamp experiments in HEK293 cells previously transfected with erg1a or erg3. The following steady-state values as well as timedependent and voltage-dependent parameters of ergla and erg3 channels were determined by using the appropriate pulse protocols (see Results for detailed description of protocols): steady-state activation and inactivation, time constants of development of activation and deactivation, development of inactivation and recovery from inactivation (Sturm et al., 2005). From these data, the forward and backward rate constants of erg current activation and inactivation were evaluated as described by Hodgkin and Huxley (Hodgkin and Huxley, 1952). The voltage dependence of rate constants was fitted with the exponential equation: $f(x)=A_{\exp }[k$ $\left(v-v_{0}\right)$ ], with $v$ the membrane potential (in millivolts), and $v_{0}=-120$ $\mathrm{mV}$. The activation and inactivation rate constants (means \pm SEM) for ergla $(n=4)$ and $\operatorname{erg} 3(n=4)$ are summarized in Table 2.

Erg1a and erg3 channels were constructed with the channel builder of NEURON 7.1 and incorporated into the KGR model. Conductance of ergla or erg3 channels and stimulus strength were changed until the modeled frequency of action potentials equaled that of the actual Purkinje cell recordings.
Table 2. Summary of activation and inactivation rate constants (means \pm SEM) for erg1a and erg3

\begin{tabular}{lcr}
\hline & $A\left(\mathrm{~ms}^{-1}\right)$ & $k\left(\mathrm{mV}^{-1}\right)$ \\
\hline Erg1a activation & & \\
$\alpha_{\mathrm{m}}$ & $0.000015 \pm 0.000005$ & $0.041 \pm 0.003$ \\
$\beta_{\mathrm{m}}$ & $0.031 \pm 0.004$ & $-0.038 \pm 0.0013$ \\
Erg1a inactivation & & \\
$\alpha_{\mathrm{h}}$ & $0.0029 \pm 0.0006$ & $0.033 \pm 0.0012$ \\
$\beta_{\mathrm{h}}$ & $0.759 \pm 0.082$ & $-0.032 \pm 0.0012$ \\
Erg3 activation & & \\
$\alpha_{\mathrm{m}}$ & $0.0008 \pm 0.0003$ & $0.031 \pm 0.003$ \\
$\beta_{\mathrm{m}}$ & $0.062 \pm 0.016$ & $-0.032 \pm 0.002$ \\
Erg3 inactivation & & \\
$\alpha_{\mathrm{h}}$ & $0.0015 \pm 0.0006$ & $0.027 \pm 0.003$ \\
$\beta_{\mathrm{h}}$ & $1.23 \pm 0.32$ & $-0.033 \pm 0.003$ \\
\hline
\end{tabular}

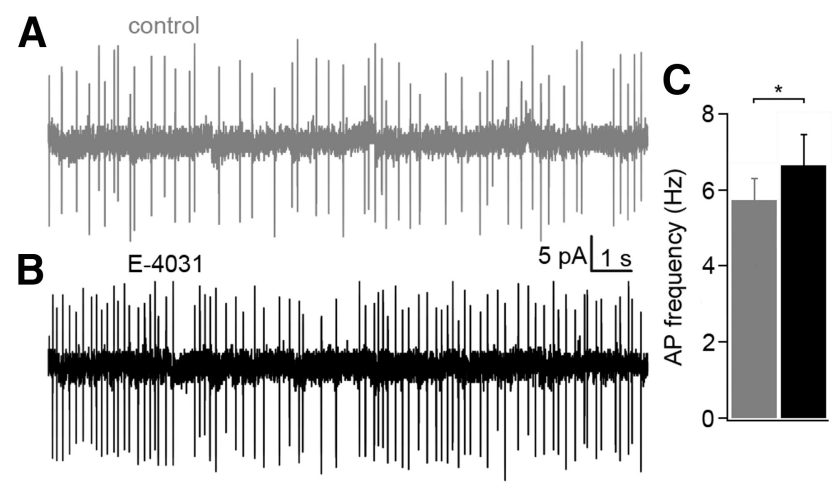

Figure 1. Increase in the frequency of spontaneous activity in a Purkinje cell of a neonatal mouse (P8) after blockage of erg channels. $\boldsymbol{A}, \boldsymbol{B}, 0$ n-cell recording measured in ACSF before ( $\boldsymbol{A})$ and during $(\boldsymbol{B})$ application of $5 \mu \mathrm{M} E-4031$. $\boldsymbol{C}$, Increase of action current frequency from $5.7 \pm$ $0.6 \mathrm{~Hz}$ to $6.6 \pm 0.8 \mathrm{~Hz}\left({ }^{*} p<0.05 ; n=10\right)$.

\section{Results}

\section{Erg channels decrease excitability}

To investigate the function of erg currents in Purkinje cells of neonatal mice, we performed current-clamp experiments in acute slices from the cerebellum of P5-P10 mice and investigated the effect of erg channel blockage on the frequency of action potential firing. The recordings were done in ACSF containing 5 $\mathrm{mM} \mathrm{K}^{+}$and $2 \mathrm{mM} \mathrm{Ca}^{2+}$ in the presence of synaptic blockers. The irregular spontaneous firing shown in the on-cell recording of Figure 1 was characteristic for Purkinje cells of neonatal mice. Application of E-4031, a specific erg channel blocker (Weinsberg et al., 1997), increased the firing frequency from $5.7 \pm 0.6 \mathrm{~Hz}$ to $6.6 \pm 0.8 \mathrm{~Hz}(n=10, p<0.05)$. In whole-cell recordings, the resting potential was $-57 \pm 3 \mathrm{mV}(n=8$; data not shown). This value is similar $(-56.2 \pm 2.4 \mathrm{mV})$ to that reported by Sacco et al. (2003). The spontaneous activity vanished after hyperpolarizing the membrane potential to $\leq-60 \mathrm{mV}$. One hundred picoamp depolarizing current pulses elicited repetitive activity (Fig. 2A). The threshold potential was determined by constructing a phase plane plot (Bean, 2007). Figure $2 B$ shows that the first action potential exhibited a more negative threshold potential $\left(V_{\mathrm{th}}=\right.$ $-39.6 \pm 0.9 \mathrm{mV}, n=24)$ than the action potentials during the subsequent repetitive activity $\left(V_{\mathrm{th}}=-38.0 \pm 0.7 \mathrm{mV}\right)$. E-4031 application shifted the threshold potentials by -2.5 and -2.6 $\mathrm{mV}$, respectively, i.e., for the first action potential to $-42.1 \pm 0.9$ $\mathrm{mV}(p<0.001 ; n=24)$ and for the subsequent action potentials to $-40.6 \pm 0.8 \mathrm{mV}(p<0.001)$. The decreased threshold potential can be explained by a decrease in outward $\mathrm{K}^{+}$current across 
the soma membrane and a slight increase in membrane resistance in the presence of E-4031. Membrane resistance was determined from the membrane potential change induced by a $100 \mathrm{pA}$ depolarizing current in the presence of TTX to avoid the activation of $\mathrm{Na}$ channels (control, $168 \pm 12 \mathrm{M} \Omega$; in the presence of E-4031, $220 \pm 8 \mathrm{M} \Omega ; n=5 ; p<0.01)$.

The instantaneous firing frequency (IFF) calculated from the first interspike interval increased from $32 \pm 3 \mathrm{~Hz}$ to $39 \pm$ $4 \mathrm{~Hz}(p<0.001, n=24)$. The mean frequency determined from all action potentials elicited with the $100 \mathrm{pA}$ depolarizing pulse of $500 \mathrm{~ms}$ duration was $25 \pm 1 \mathrm{~Hz}$ in the absence of E-4031 and increased to $29 \pm 2 \mathrm{~Hz}(p<0.001, n=24)$ in the presence of E-4031. The IFF of the first three action potentials decreased faster than during the remaining repetitive activity. Although in the presence of E-4031 there was a significant increase in IFF, accommodation remained absent. In 12 cells exhibiting at least 11 action potentials during the depolarizing pulse, the slope of decrease in the mean frequency calculated from the third to the 11th interspike number showed no statistically significant difference before and after application of E-4031 (Fig. 2C). The firing frequency increased with the strength of the depolarizing current and reached a saturating value of $\sim 45 \mathrm{~Hz}$ at depolarizing currents $>200 \mathrm{pA}$ (Fig. 2D). This maximal frequency was not influenced by E-4031. In conclusion, erg current in Purkinje cells of neonatal mice shifted the threshold potential to more positive membrane potentials and decreased the frequency of action potential firing without inducing accommodation. The afterhyperpolarization (AHP) of action potentials elicited with $3 \mathrm{~ms}$ depolarizations was determined from the potential difference between the resting potential and the peak hyperpolarization following a single action potential. The AHP did not change significantly in the presence of E-4031 (control, $-5.8 \pm 1.0 \mathrm{mV}$; in the presence of E- $4031,-5.0 \pm 1.0 \mathrm{mV} ; n=7, p>0.05)$. Sacco et al. (2003) also found no effect of the erg current on the AHP in Purkinje cells.

Erg current activation within the subthreshold potential range was investigated with a ramp protocol. The measurements were performed in $5 \mathrm{mM} \mathrm{K}^{+}$ACSF containing a low $\mathrm{Ca}^{2+}$ concentration (1 mM) for a better isolation of erg current (Fig. 3A). E-4031 application induced a steeper slope of depolarization, a more negative threshold potential, and a strong increase in action potential frequency. The steady-state voltage during the ramp reached values close to $-20 \mathrm{mV}$. Therefore, action potential generation was abolished due to $\mathrm{Na}^{+}$channel inactivation. To measure the erg current activated by the ramp pulse, we used the ramp-induced membrane depolarization and the superimposed sequence of action potentials (Fig. $3 A a$ ) as a potential template (Fig. $3 B$ ) in voltage-clamp recordings (action potential clamp) before and during application of E-4031. Each potential template elicited a slowly activating steady-state current and, during the action potentials, transient inward and outward currents (Fig. $3 C)$. Subtraction of the current response obtained in the presence of E-4031 from the control current revealed a slowly increasing E-4031-sensitive current reaching an amplitude of $\sim 40 \mathrm{pA}$ (Fig. $3 D)$. The mean current density of the E-4031-sensitive current was $0.43 \pm 0.06 \mathrm{pA} / \mathrm{pF}(n=5)$.

\section{Biophysical properties of erg currents in Purkinje cells}

The observed E-4031-induced changes in the threshold potential and frequency of action potential firing of Purkinje cells indicated that the erg current activated near the resting potential of $\sim-60$ $\mathrm{mV}$. The negligible E-4031 influence on accommodation suggested that the gating kinetics of the Purkinje cell erg current were fast. To measure the biophysical properties of the erg current, we performed voltage-clamp experiments in Purkinje cells in acute slices from the cerebellum of P5-P10 mice, i.e., the same age at which the current-clamp experiments were performed. To increase erg $\mathrm{K}^{+}$channel conductance, we raised the extracellular $\mathrm{K}^{+}$concentration to $40 \mathrm{~mm}$ (Shibasaki, 1987; Sturm et al., 2005). In addition, the ACFS was prepared without $\mathrm{Ca}^{2+}$ to prevent the activation of voltage-dependent $\mathrm{Ca}^{2+}$ currents and $\mathrm{Ca}^{2+}$. activated $\mathrm{K}^{+}$currents. The holding potential was set to $-80 \mathrm{mV}$ to deactivate all erg channels before investigating the voltage dependency of erg current activation (Fig. 4). To allow for the slow 
Aa

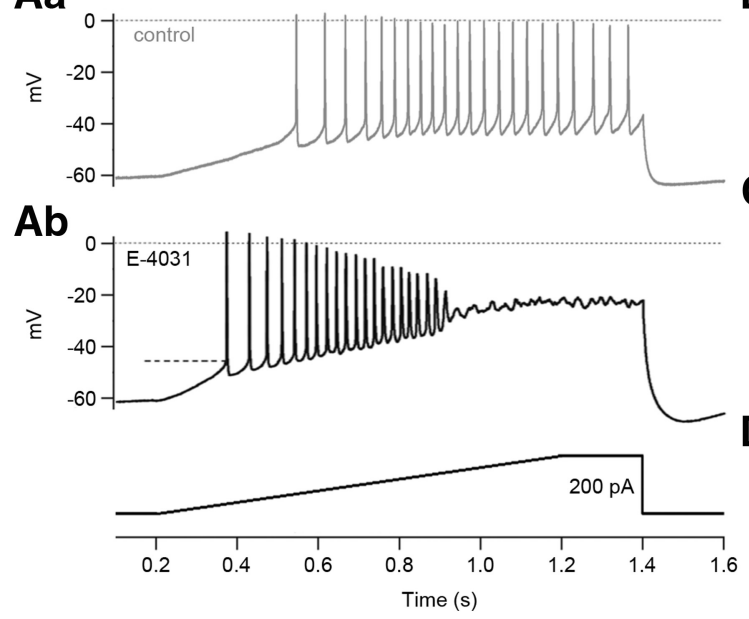

B

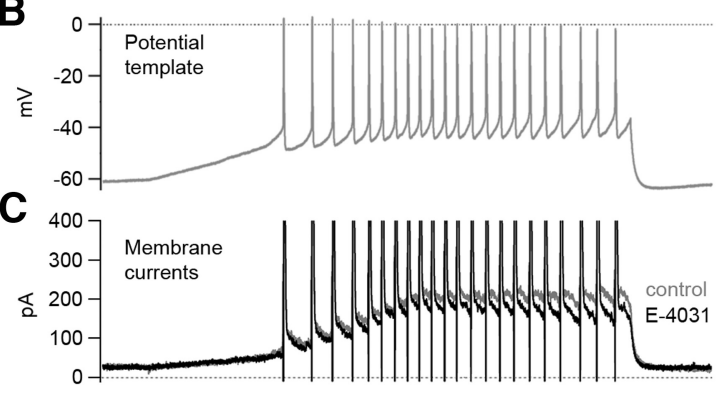

D

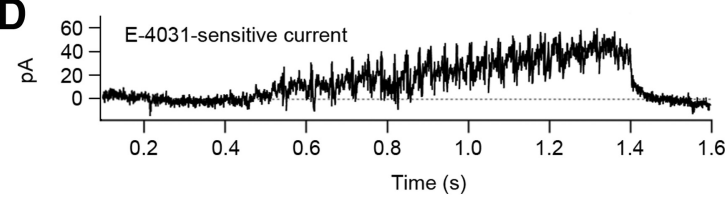

Figure 3. Action potential clamp reveals erg current activation during a ramp pulse. $\boldsymbol{A}$, Recordings of action potentials elicited with a ramp pulse before $(\boldsymbol{A a})$ and during ( $\boldsymbol{A} \boldsymbol{b})$ application of $5 \mu \mathrm{M}$ E-4031. A Purkinje cell was depolarized by injecting a $1 \mathrm{~s}$ ramp pulse from 0 to $200 \mathrm{pA}$ followed by a $200 \mathrm{~ms}$ constant current injection of $200 \mathrm{pA}$ (see pulse protocol beneath membrane potential recording of $\boldsymbol{A} \boldsymbol{b}$ ). Dashed lines indicate threshold potential. $\boldsymbol{B}-\boldsymbol{D}$, Action potential clamp. $\boldsymbol{B}$, The membrane potential changes shown in $\boldsymbol{A} \boldsymbol{a}$ were used as a potential template. $\boldsymbol{C}$, Superimposed membrane currents recorded before (gray) and during (black) application of $5 \mu \mathrm{m}$ E-4031. Outward and inward currents were cut at 400 and 0 pA, respectively. D, E-4031-sensitive current obtained by subtracting the current trace recorded in the presence of E-4031 from the control.

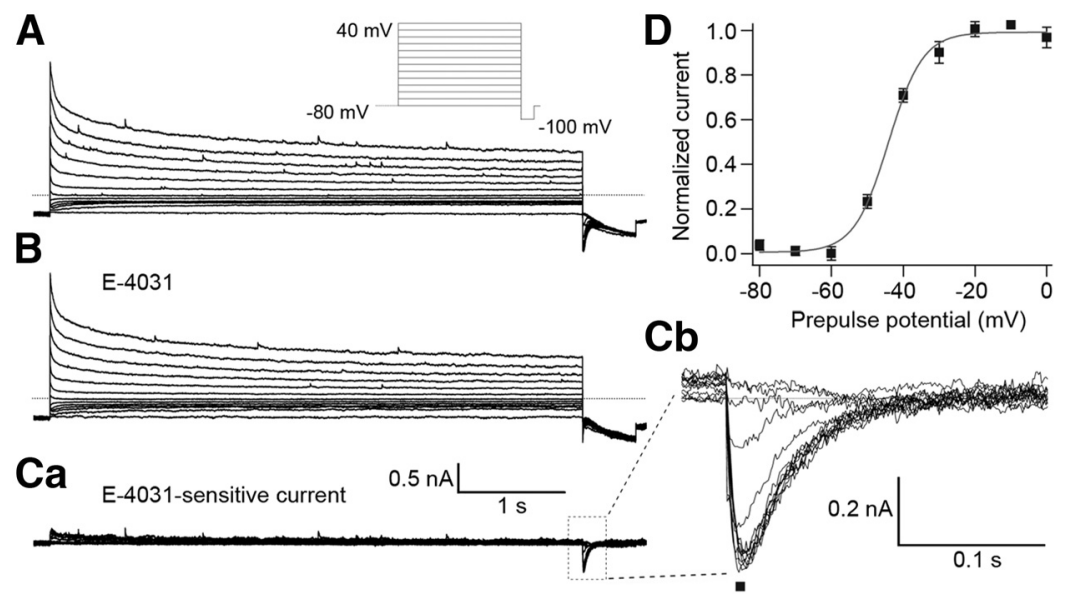

Figure 4. Voltage-dependent activation of Purkinje cell erg current. $\boldsymbol{A}, \boldsymbol{B}$, Membrane currents recorded before $(\boldsymbol{A})$ and during (B) application of $5 \mu \mathrm{m}$ E-4031. Extracellular solution, $40 \mathrm{~mm} \mathrm{~K}{ }^{+}$. From a holding potential of $-80 \mathrm{mV}$, potential steps of $5 \mathrm{~s}$ duration were applied from -80 to $40 \mathrm{mV}$ in $10 \mathrm{mV}$ intervals (see $\boldsymbol{A}$, pulse diagram). Ca, E-4031-sensitive current obtained by subtracting the membrane currents shown in $\boldsymbol{B}$ from those in $\boldsymbol{A}$. $\boldsymbol{C} \boldsymbol{b}$, Enlarged erg tail currents measured at $-100 \mathrm{mV}$. D, Peak tail current amplitudes $(\boldsymbol{C} \boldsymbol{b}, \square)$ were normalized, plotted against prepulse potentials, and fitted with a Boltzmann function $\left(V_{1 / 2}=\right.$ $-44.1 \mathrm{mV}, k=4.8 \mathrm{mV} ; n=7)$.

time course of erg channel activation, $5 \mathrm{~s}$ depolarizing test pulses were used (Wang et al., 1997; Schonherr et al., 1999). Membrane currents were elicited with potentials between -80 and $40 \mathrm{mV}$ in steps of $10 \mathrm{mV}$ followed by a negative step to $-100 \mathrm{mV}$ to evoke tail currents. The time course of the tail currents revealed the erg current hook, which is characteristic for erg currents and due to fast recovery from inactivation and slow deactivation. Tail current amplitudes were normalized, mean values were plotted against test pulse potentials, and a Boltzmann function was fitted to the data points to obtain the activation curve. The erg current commenced to activate near $-60 \mathrm{mV}$ and reached $50 \%$ of its maximal amplitude near $-44 \mathrm{mV}$ (Fig. $4 D$; Table 3).

We used a deactivation protocol to determine the voltagedependent kinetics of recovery from inactivation and deactivation of Purkinje cell erg currents. From a holding potential of $-20 \mathrm{mV}, 1 \mathrm{~s}$ test pulses from 40 to $-120 \mathrm{mV}$ in steps of $10 \mathrm{mV}$ were applied. Each test pulse was preceded by a $2 \mathrm{~s}$ prepulse to $20 \mathrm{mV}$ to ensure full erg channel activation (see pulse protocol in Fig. 5) (Hirdes et al., 2009). Test pulses more negative than $-60 \mathrm{mV}$ elicited membrane currents consisting of an initial transient erg current and a subsequent large h current. After blockage of erg currents by E-4031 (Fig. 5B), the E-4031sensitive currents were obtained (Fig. 5C). From exponential fits to the transient erg currents elicited with potential steps between -60 and $-90 \mathrm{mV}$, the time constants of recovery from inactivation $\left(\tau_{\text {rec }}\right)$ and deactivation $\left(\tau_{\text {deac }}\right.$; Fig. $5 D, E$; Table 3 ) were determined. Deactivation of currents elicited with potentials between -100 and $-120 \mathrm{mV}$ were well described with the sum of two exponential functions revealing a fast and a slow component of deactivation (Fig. 5E). The time course of erg current activation at $20 \mathrm{mV}$ was determined by an envelope-of-tail protocol (Wang et al., 1997). From a holding potential of $-80 \mathrm{mV}$, the membrane potential was stepped to $20 \mathrm{mV}$ to activate the erg current. Gradual prolongation of this depolarization increased the amplitude of the erg current elicited by the hyperpolarizing step to $-100 \mathrm{mV}$. A single exponential function was fit to the increase of the normalized tail current amplitudes, yielding the time constant of erg current activation at $20 \mathrm{mV}(\tau=$ $53.7 \pm 9.5 \mathrm{~ms} ; n=5)$.

\section{Biophysical properties of erg currents in Purkinje cells resemble those of erg1 and erg3 currents}

Purkinje cells express all erg channel subunits, both at the mRNA and protein level (Saganich et al., 2001; Papa et al., 2003; Guasti et al., 2005; Hagendorf et al., 2009). We therefore compared the time-dependent and voltage-dependent properties of the native erg current with currents mediated by erg1a, erg1b, erg2, and 
Table 3. Biophysical properties of erg currents ${ }^{a}$

\begin{tabular}{|c|c|c|c|c|c|c|c|c|}
\hline erg current & $\begin{array}{l}\tau(\mathrm{ms}) \text {, recovery } \\
\text { from inactivation } \\
\text { at }-100 \mathrm{mV}\end{array}$ & $\begin{array}{l}\tau(\mathrm{ms}) \text {, deactivation } \\
\text { at }-100 \mathrm{mV}\end{array}$ & $n$ & $\begin{array}{l}\text { Activation curve } \\
V_{0.5}(\mathrm{mV})\end{array}$ & $k(\mathrm{mV})$ & $n$ & $\begin{array}{l}\% \text { of maximum } \\
\text { erg current activation } \\
\text { during ramp pulse }\end{array}$ & $n$ \\
\hline r-erg1a & $4.3 \pm 0.9$ & $79.5 \pm 30.9$ & 3 & $-41.9 \pm 3$ & $5.2 \pm 0.5$ & 3 & $3.0 \pm 1.0$ & 8 \\
\hline r-erg1b & $3.3 \pm 0.9$ & $14.6 \pm 1.5$ & 5 & $-25.4 \pm 1.7$ & $7.7 \pm 0.9$ & 6 & $3.7 \pm 0.8$ & 9 \\
\hline r-erg2 & $5.9 \pm 0.3$ & $53.3 \pm 4.0$ & 4 & $-2.0 \pm 2.0$ & $5.9 \pm 0.7$ & 6 & $1.8 \pm 0.5$ & 5 \\
\hline r-erg3 & $2.1 \pm 0.5$ & $16.9 \pm 1.9$ & 4 & $-44.2 \pm 1.8$ & $4.2 \pm 0.6$ & 7 & $15.0 \pm 4.0$ & 9 \\
\hline erg Purkinje cells & $3.0 \pm 0.5$ & $22.8 \pm 3.2$ & 6 & $-44.3 \pm 0.4$ & $4.9 \pm 0.6$ & 7 & $\sim 17$ & 7 \\
\hline
\end{tabular}

${ }^{a}$ Biophysical properties of heterologously expressed erg currents and native erg currents measured in Purkinje cells of neonatal mice (P5-P10). All measurements were performed in an extracellular solution containing 40 mu $\mathrm{K}^{+}$

erg3 channels expressed in vitro under similar conditions, i.e., at $40 \mathrm{~mm}$ extracellular $\mathrm{K}^{+}$and no $\mathrm{Ca}^{2+}$. Figure $6 A$ shows that activation curves of erg1a and erg3 currents superimposed with the activation curve of the native Purkinje cell erg current, whereas the erg1b and erg2 ones were shifted by $\sim 20$ and $>40 \mathrm{mV}$ to more positive potentials, respectively (Table 3 ). The time constants of recovery from inactivation and deactivation of native Purkinje cell erg current resembled those of erg1b and erg3 currents. The time constant of Purkinje cell erg current activation at $20 \mathrm{mV}$ was $54 \mathrm{~ms}$ (see above), a value smaller than those previously determined for heterologously expressed erg currents under similar experimental conditions (erg3, 95 ms; erg1b, 106 ms; ergla, 215 ms; erg2, 821 ms; Hirdes et al., 2005). Together, the biophysical properties of Purkinje cell erg currents resembled most closely erg1 and erg3 currents. The deviations of Purkinje cell erg currents from those mediated by heterologously expressed homomeric erg1 and erg3 channels could be due to the formation of heteromeric erg1/erg3 channels or of erg1 channels modified by ancillary subunits or post-translational modification.

Since in Purkinje cells action potential recordings and action potential clamp experiments were done in ACSF containing $5 \mathrm{mM} \mathrm{K}^{+}$and 2 or $1 \mathrm{mM} \mathrm{Ca}^{2+}$, respectively, we performed voltage-clamp experiments in Ringer's solution containing $1 \mathrm{mM} \mathrm{Ca}^{2+}$ to obtain steady-state activation and inactivation curves of erg 1a, erg1b, erg2, and erg3 channels. Steadystate inactivation of erg channels was determined with the protocol described in the legend to Figure 6. The activation curves measured in $5 \mathrm{~mm}$ Ringer's solution were shifted to more positive membrane potentials compared with those measured in $40 \mathrm{mM} \mathrm{K}^{+}$(Fig. 6B; Wang et al., 1997; Sturm et al., 2005). Superimposing erg3 and ergla activation and inactivation curves showed that the erg 3 window current ranged from $-60 \mathrm{mV}$ to positive membrane potentials. In contrast, the ergla window current was much smaller and located at more positive membrane potentials. Activation and inactivation curves of erg2 and erg1b were not included in Figure $6 B$, since their window currents were smaller than those of ergla currents and located at even more positive membrane potentials.

To measure the erg current elicited by a train of action potentials, we stimulated Purkinje cells and HEK293 cells transiently expressing one of the four erg channel subunits with the action potential template of Figure $3 B$. The currents shown in Figure $7 B-F$ are E-4031-sensitive currents and the arrows indicate the point in time at which the erg current of the Purkinje cell started to activate (Fig. $7 B$ ). In Purkinje cells, the potential template activated the erg current within the subthreshold region and reached a final amplitude of $30 \pm 3 \mathrm{pA}(n=5)$. Ergla and erg1b currents activated with a delay (Fig. $7 C, D$, arrows), i.e., at suprathreshold potentials and erg2 currents remained very small during the whole ramp-like pulse (Fig. 7E). In HEK293 cells expressing erg3 channels, the erg current activated near threshold and reached a large steady-state current $(340.9 \pm 88.9 \mathrm{pA} ; n=9$; Fig. $7 F$ ). Since absolute erg current amplitudes recorded in transiently transfected HEK293 cells are difficult to compare, we calibrated erg channel expression by determining the percentage of maximal erg current that each of the four erg currents attained during the ramp pulse. The maximal erg current of each type of erg channel was determined from the erg tail current amplitude elicited with the $-100 \mathrm{mV}$ pulse of the activation protocol (Fig. 4; data not shown). The highest percentage was determined for erg3 $(15 \pm 4 \% ; n=9)$, much smaller percentages were measured for 

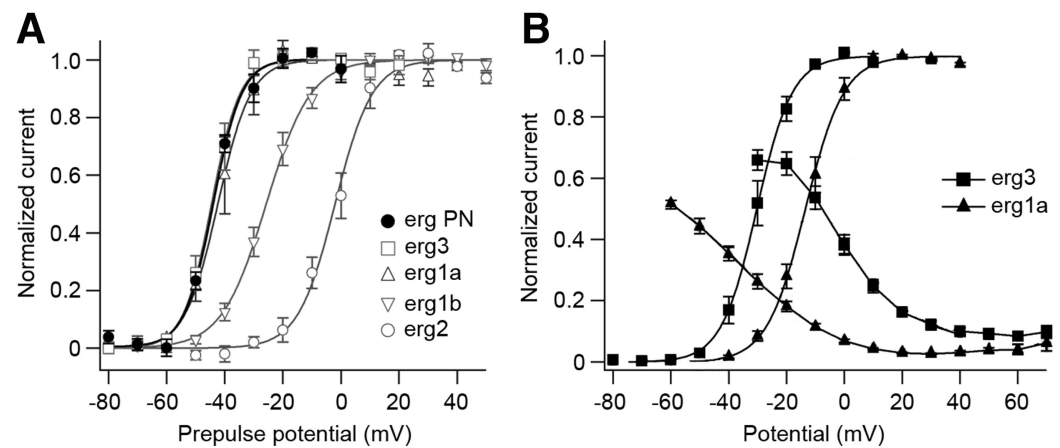

Figure 6. Comparison of biophysical properties of native and heterologously expressed erg currents. $A$, Voltage dependence of erg current activation, external solution, $40 \mathrm{~mm} \mathrm{~K}^{+}$. Measurements were made in Purkinje cells and in HEK293 cells following transient transfection of erg1a, erg1b, erg2, or erg3. Activation protocol as in Figure 4. Bolzmann fits to the mean values of the activation curves yielded $V_{1 / 2}$ and $k$ values as given in Table $3 . \boldsymbol{B}$, Voltage-dependent activation and inactivation recorded in HEK293 cells transiently transfected with erg1a or erg3. External solution, $5 \mathrm{~mm} \mathrm{~K}^{+}, 1 \mathrm{~mm} \mathrm{Ca}^{2+}$. Activation protocol as in Figure 4. Bolzmann fits to the mean values of the activation curves yielded the following $V_{1 / 2}$ and $k$ values, respectively: $\operatorname{erg} 3(-30.3 \mathrm{mV}$, $6.2 \mathrm{mV} ; n=6)$, erg1a ( $-13.5 \mathrm{mV}, 6.7 \mathrm{mV} ; n=6)$. Inactivation curves were measured in the same external solution using the following pulse protocol: from a holding potential of $-20 \mathrm{mV}$, a $10 \mathrm{~ms}$ (erg1a) or $5 \mathrm{~ms}$ (erg3) pulse to $-100 \mathrm{mV}$ was followed by $100 \mathrm{~ms}$ potential steps from -100 to $70 \mathrm{mV}$ in steps of $10 \mathrm{mV}$. Steady-state inactivation for each potential was determined from the ratio of the steady-state and initial peak current.
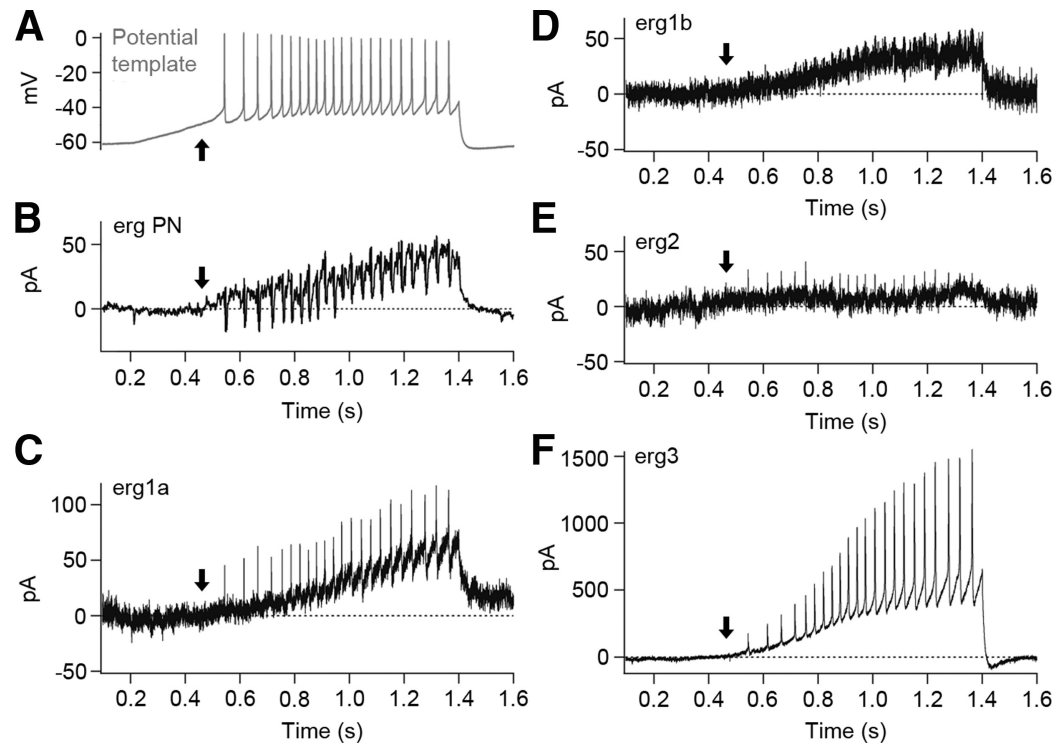

Figure 7. $A$, Erg currents elicited with the action potential template (same template as in $A \boldsymbol{a}$ of Fig. 3). External solution, $5 \mathrm{~mm}$ $\mathrm{K}^{+}, 1 \mathrm{~mm} \mathrm{Ca}{ }^{2+} . \boldsymbol{B}-\boldsymbol{F}, \mathrm{E}-4031$-sensitive currents obtained by subtracting the currents elicited with the potential template shown in $\boldsymbol{A}$ in the presence of E-4031 from control currents. E-4031-sensitive currents of a Purkinje cell $(\boldsymbol{B})$, HEK293 cell transfected with rat erg1a $(\boldsymbol{C}), \operatorname{erg} 1 \mathrm{~b}(\boldsymbol{D}), \operatorname{erg} 2(\boldsymbol{E})$, or erg3 $(\boldsymbol{F})$.

erg1a $(3 \pm 1 \% ; n=8), \operatorname{erg} 1 \mathrm{~b}(3.7 \pm 0.8 \% ; n=9)$, and erg2 channels $(1.8 \pm 0.5 \% ; n=5)$. Since it was not possible to reliably isolate the native erg current from the other conductances in 5 $\mathrm{mm} \mathrm{K}^{+}$ACSF, we used an ACSF containing a slightly higher external $\mathrm{K}^{+}$concentration $(8 \mathrm{~mm})$. The maximal current amplitude in this solution was $173 \pm 19 \mathrm{pA}(n=7)$. Taking into account that the erg $\mathrm{K}^{+}$conductance is slightly larger in $8 \mathrm{~mm}$ compared with $5 \mathrm{~mm} \mathrm{~K} \mathrm{~K}^{+}$ACSF, the relative native erg current amplitude was at least $17 \%$, a value similar to $15 \%$ obtained for erg3 channels (see above). These data indicated that, at a physiological external $\mathrm{K}^{+}$concentration, erg3 channel subunits are important components of the erg channels mediating the steadystate erg current activated by the ramp-like pulse in Purkinje cells. The small erg current shown in Figure $3 D$ was elicited with the depolarizing ramp pulse from -60 to $\sim-40 \mathrm{mV}$. Figure $6 B$ shows that within this potential range only erg 3 channels can be activated. In addition, the erg3 activation curve shows that, upon a depolarization to $-40 \mathrm{mV}$, $\sim 20 \%$ of the maximal erg current would be activated.

\section{Blockage of the erg current in Purkinje cells by erg channel-specific toxins}

To investigate the subunit composition of erg channels in Purkinje cells of neonatal mice, we tested their sensitivity to two toxins, the scorpion toxin BeKm-1 (Korolkova et al., 2001) and the sea anemone toxin APETx1 (Diochot et al., 2003). In HEK293 cells expressing erg1, erg2, or erg3 channels, BeKm-1 (100 nM) reduced the peak erg tail currents by $50 \pm 4 \%$ (erg1a; $n=5), 100 \%$ $(\operatorname{erg} 2 ; n=6)$, and $33 \pm 2 \%(\operatorname{erg} 3 ; n=5$; Fig. $8 A-C)$. The time course of recovery from current reduction induced by BeKm-1 was similar in erg 1 and erg 3 channels (erg1a: $\tau_{\text {off }}=10.3 \pm 2.5 \mathrm{~s} ; n=5 ; \mathrm{erg} 3: \tau_{\text {off }}=10.1 \pm$ $2.5 \mathrm{~s} ; n=5)$. In contrast, recovery from BeKm-1-induced blockage of erg2 current was very poor in three experiments and very slow in one experiment $\left(\tau_{\text {off }}=370 \mathrm{~s}\right)$, similar to the time course recently published $\left(\tau_{\text {off }}=330 \mathrm{~s}\right.$; Restano-Cassulini et al., 2006). APETx1 $(1 \mu \mathrm{M})$ reduced the peak erg tail current amplitudes by $25 \pm 2 \%$ (ergla; $n=$ $15), 15 \pm 2 \%(\operatorname{erg} 2 ; n=7)$, and $3 \pm 2 \%$ (erg3; $n=5$; Fig. $8 A-C$ ). These effects of BeKm-1 and APETxl on erg1-3 currents were similar to those previously published (Restano-Cassulini et al., 2006). With acute slices obtained from the cerebella of P7 mice BeKm-1 (100 nM) blocked the E-4031sensitive current by $53 \pm 8 \%$ (SEM; $n=3$ ). The time course of wash-out of the toxininduced current reduction was relatively fast $\left(\tau_{\text {off }}=36 \pm 14 s ; n=3\right)$. Application of APETx1 $(1 \mu \mathrm{M})$ in the slice experiments reduced the native E-4031-sensitive current by $22 \pm 4 \%(n=3)$. The data clearly excluded homomeric erg2 and erg3 channels and suggested that the native erg channel is predominantly composed of ergla subunits. The faster gating kinetics, however, argue for the formation of heteromeric erg1/erg3 channels, unless they are evoked by other modifications of ergla channels. Therefore, we also studied the effect of BeKm-1 and APETx1 on erg $1 /$ erg 3 channels transiently expressed in HEK 293 cells as erg1/erg3 concatemers (Wimmers et al., 2002). BeKm-1 (100 nM) reduced the erg1/erg3 current by $56 \pm 4 \%(n=5)$ and APETx1 $(1 \mu \mathrm{M})$ by $21 \pm 2 \%(n=5$; Fig. $8 D)$. Obviously, the currents mediated by homomeric ergla and concatemeric erg1/erg3 channels were reduced by the toxins to the same degree.

\section{Erg channel expression in the cerebellum}

In the cerebellum of the adult mouse, all erg channel subunits are strongly expressed in Purkinje cells and in neurons of the deep cerebellar nuclei; moderate expression occurs in Golgi cells, while other cerebellar neurons show very weak expression (Guasti et al., 
2005). Using RT-PCR, we found that all genes (erg1a, erg1b, erg2, erg3) are also expressed in the cerebellum of the neonatal mouse (P6). We then performed qPCR with cDNA obtained from cerebella of six neonatal mice, and the transcript abundance of each erg subunit was determined relative to that of pgk1 and Tfr as reference transcripts. After determination of mRNA abundance of each erg channel subunit relative to the reference genes, the expression level of each erg mRNA was expressed in percentage of the total erg transcript content. Table 4 shows that ergla plus ergla-uso contributed $\sim 50 \%$, the next abundant transcript was erg2, and $\sim 14 \%$ of the total erg mRNA abundance was covered by erg3 transcripts. Erglb and erglb-uso were expressed at a very low level. The results show that all erg subunits are present in the mouse cerebellum. Obviously, erglb is of much lower importance in the mouse cerebellum than in the human heart (Larsen and Olesen, 2010). Since a contribution of erg2 channel subunits is very unlikely due to the results of the toxin experiments and the biophysical properties of the native erg current (Table 3 ), the native erg current could be mediated by heteromeric erg1/erg3 or modified ergla channels. In the human heart, the HERG1a-uso transcript content is twice that of HERG1a (Kupershmidt et al., 1998). Assuming a similar ratio in the mouse cerebellum, the total transcript content for a channel-forming ergla subunit would decrease considerably.

To investigate whether the transcript abundance of the different erg channel subunits changed during development, we performed qPCR in six cerebella of 7-week-old mice. As in the cerebella of neonatal mice, we determined the transcript abundance of erg channel subunits in relation to that of pgk1 and Tfr. These two genes were chosen as reference genes because they are stably expressed during development of the mouse cerebellum (Boda et al., 2009). Table 4 shows that the transcript abundance of erg3 subunits significantly decreased by $\sim 50 \%$, whereas the relative transcript abundance of ergla plus ergla-uso, erglb plus erg1b-uso, and erg2 did not change during development. The decrease in erg 3 channel subunit expression during development underlines its possible importance for the formation of neonatal erg channels.

\section{Simulation of the effects of erg1a and erg3 conductance on repetitive activity}

We further investigated the role of subthreshold erg currents for Purkinje cell repetitive activity in a computer simulation using the KGR Purkinje cell model (Khaliq et al., 2003; see Materials and Methods). The control simulation represented repetitive activity $(38 \mathrm{~Hz})$ of a Purkinje cell elicited with a $500 \mathrm{~ms}$ depolarizing pulse in the absence of erg channel conductance (Fig. 9, top). In this simulation, no accommodation was present, reproducing the repetitive activity of a Purkinje cell recorded in the presence of E-4031 (Fig. 2Ab). Addition of erg3 conductance nicely reproduced the observation of Figure $2 A$ that the erg current in Purkinje cells of neonatal mice reduced the frequency of action potential firing $(30 \mathrm{~Hz})$ without inducing accommodation. Throughout the $500 \mathrm{~ms}$ depolarizing pulse, the interspike inter-
B

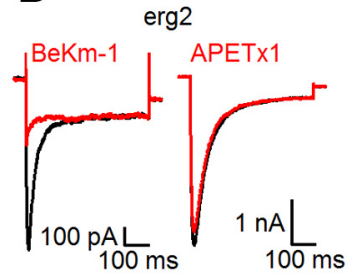

C

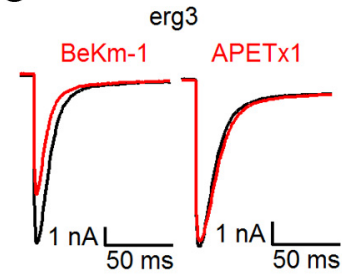

$\mathbf{E}$
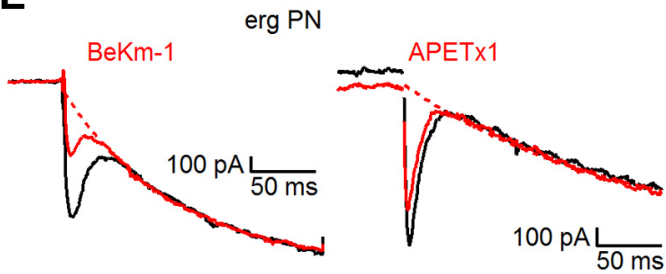

Figure 8. The toxins BeKm-1 and APETx1 reduced the currents mediated by erg1a and erg1a/erg3 concatemers to a similar 列

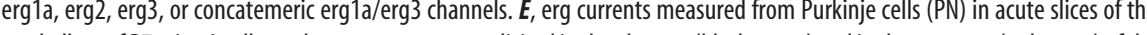

Table 4. Expression of erg channel subunits in the cerebellum of P6 and 7-week-old mice $^{a}$

\begin{tabular}{|c|c|c|c|c|c|}
\hline \multirow[b]{2}{*}{ Gene } & \multicolumn{2}{|l|}{ P6 mice } & \multicolumn{2}{|l|}{ W7 mice } & \multirow[b]{2}{*}{$p$} \\
\hline & $\begin{array}{l}\text { Relative expression } \\
\text { level }(\%)\end{array}$ & $n$ & $\begin{array}{l}\text { Relative expression } \\
\text { level }(\%)\end{array}$ & $n$ & \\
\hline erg1a + erg1a-uso & $48.4 \pm 3.1$ & 6 & $51.0 \pm 2.6$ & 6 & 0.589 \\
\hline erg1b + erg1b-uso & $2.2 \pm 0.6$ & 6 & $3.0 \pm 0.7$ & 6 & 0.699 \\
\hline erg2 & $35.3 \pm 2.5$ & 6 & $38.7 \pm 2.5$ & 6 & 0.244 \\
\hline erg3 & $14.1 \pm 0.6$ & 6 & $7.3 \pm 0.6$ & 6 & 0.002 \\
\hline
\end{tabular}

${ }^{a}$ Quantitative RT-PCR: transcripts of erg subunit expression levels were normalized to the expression level of the reference gene pgk1 for P6 and adult (7-week-old) mice. The sum of all expression levels was set to $100 \%$ for both, $\mathrm{P} 6$ and 7-week-old mice, and the content of each gene in percentage of the total erg gene expression was calculated. Erg subunit expression levels of cerebella from P6 and 7-week-old mice (W7) were analyzed using ANOVA followed by the nonparametrical Mann-Whitney $U$ test. Significance levels were adjusted by Bonferroni post hoc correction. Similar results were obtained with the Tfr as reference gene.

vals remained constant, and the amplitude of the erg3 pacemaker currents and those elicited by the modeled action potentials did not change (Fig. 9, right). By contrast, addition of ergla conductance to the model decreased action potential firing and induced a pronounced accommodation, which is not observed in neonatal Purkinje cells. The duration of the interspike intervals successively increased until the threshold potential could no longer be attained. Due to the slow time course of ergla current deactivation, its amplitude continuously increased during the depolarizing pulse, thereby increasing the threshold potential (Fig. 9, lower left). Interestingly, this simulated accommodation was reminiscent of that seen in an adult Purkinje cell (Sacco et al., 2003, their Fig. 9C). In summary, combined results of electrophysiology, toxin pharmacology, $\mathrm{qPCR}$, and simulation make it very likely that the native erg current in neonatal Purkinje cells is mediated by heteromeric erg1/erg3 channels or modified erg1 channels.

\section{Activation of mGluR1 inhibits erg current}

Electrical Purkinje cell activity is modulated by activation of mGluR1 (Yamakawa and Hirano, 1999; Hartmann et al., 2008). Apparently, the modulation involves erg channels. Application of the mGluR1 activator DHPG decreased the maximal erg current 
control (no erg)

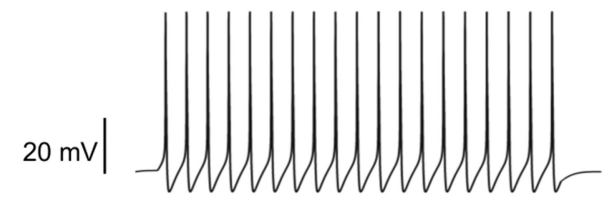

erg1a

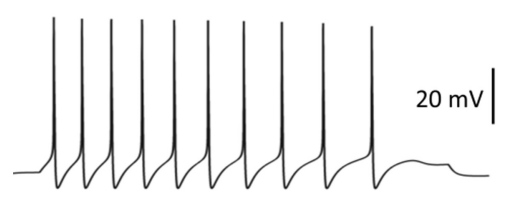

erg3

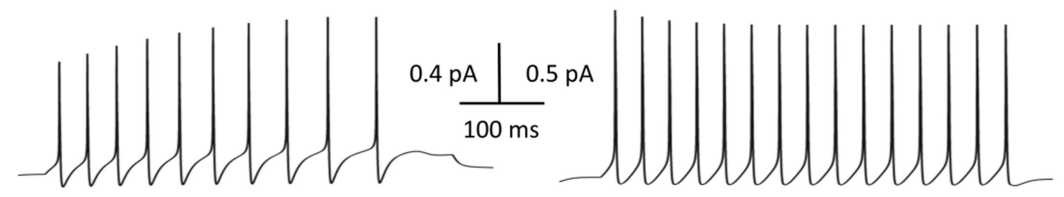

Figure 9. Simulations studying the effects of erg1a and erg3 channel conductance on Purkinje cell repetitive activity. Simulations were made with the NEURON software (Hines and Carnevale, 1997). Purkinje cell model was taken from Khaliq et al. (2003) (see Materials and Methods). Top, Repetitive activity elicited with a depolarizing current of $11 \mathrm{pA}$ (Control, no erg). Bottom left (+ erg1a), Action potentials (upper part) and erg1a currents (lower part) of Purkinje cell model after incorporation of erg1a conductance into the control model. Bottom right (+ erg3), Action potentials (upper part) and erg3 currents (lower part) of Purkinje cell model after incorporation of erg3 conductance into the control model ( + erg3). Rate constants of erg1a and erg3 current activation and inactivation were determined in voltage-clamp experiments in HEK293 cells expressing either erg1a or erg3 channels (see Materials and Methods).
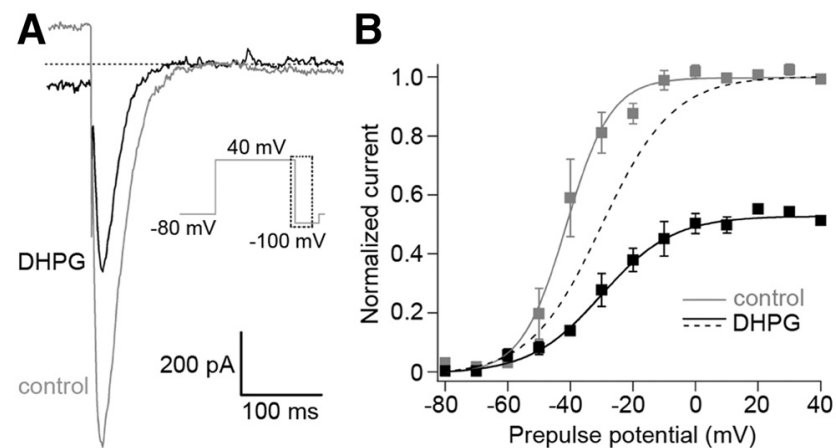

Figure 10. Inhibition of erg current in Purkinje cells by mGluR1 activation. $A$, Superimposed erg tail currents (E-4031-sensitive) recorded at $-100 \mathrm{mV}$ before (gray current trace) and during (black current trace) application of $50 \mu \mathrm{M}$ DHPG in $40 \mathrm{~mm} \mathrm{~K}^{+}$ACSF. Activation protocol as shown in Figure 4. B, Means of the peak tail currents normalized to the control before (gray) and during (black) application of DHPG plotted against prepulse potential. Fits of the data by Boltzmann functions yielded the following: $V_{1 / 2}=-41.3 \mathrm{mV}, k=7.2 \mathrm{mV} ; n=4$ (control) and $V_{1 / 2}$ $=-30.04 \mathrm{mV}, k=11.4 \mathrm{mV}$ (DHPG; $p<0.05$ paired 2-tailed $t$ test, $n=4$ ). Dashed curve, Normalized activation curve in the presence of DHPG.

to $54 \pm 2 \%(n=4$; Fig. $10 A)$ and shifted the activation curve to more positive potentials by $\sim 10 \mathrm{mV}$ (controls, $V_{1 / 2}=-40.8 \pm$ $3.4 \mathrm{mV}, k=6.6 \pm 1.1 \mathrm{mV}$; in the presence of DHPG: $V_{1 / 2}=$ $-28.5 \pm 4.5 \mathrm{mV}, k=11.6 \pm 3 \mathrm{mV} ; p<0.05, n=4$; Fig. $10 B)$. Both effects sum up to an erg current reduction of $\sim 70 \%$.

DHPG activation of mGluR1 induces a biphasic current response consisting of a transient and a steady-state component (Yamakawa and Hirano, 1999). The transient component is mediated by TRPC3 channels, since it is abolished in mice deficient of TRPC3 channels (Hartmann et al., 2008). As yet, the ion currents mediating the steady-state component are not known. To investigate a possible involvement of the erg current in the maintenance of the steady-state component the holding potential was clamped to $-40 \mathrm{mV}$ to increase the erg outward current (extracellular solution contained $2.5 \mathrm{mM} \mathrm{KCl}$ and no $\mathrm{Ca}^{2+}$ ). Application of DHPG elicited a biphasic response, characterized by a slow transient component (lasting $\sim 50$ s) and a steady-state component, very similar to the observation by Yamakawa and Hirano (1999; Fig. 11A). The DHPGinduced steady-state component was changed very little upon subsequent application of E-4031 $(-0.03 \pm 0.03 \mathrm{pA} / \mathrm{pF}$, $n=5$; Fig. $10 B$ ). In contrast, initial application of E-4031 changed the steady-state outward current by $-0.62 \pm 0.07 \mathrm{pA} / \mathrm{pF}$ $(n=13 ; p<0.001$, unpaired $t$ test; Fig. $11 C)$. When DHPG application followed that of E-4031, the elicited transient inward current was still present, whereas the steady-state current was almost absent $(-0.11 \pm 0.01 \mathrm{pA} / \mathrm{pF}, n=5$; Fig. $11 C)$. In contrast, the DHPG-induced steady-state current component in the absence of E-4031 was significantly larger $(-0.70 \pm$ $0.15 \mathrm{pA} / \mathrm{pF}, n=5, p<0.01$, unpaired $t$ test) and very similar to the change induced by E-4031 alone (Fig. 11D). These results indicated that erg channels mediate at least part of the steady-state current component of the mGluR1 response. The mean peak amplitude of the DHPG-induced current was $-1.0 \pm 0.2 \mathrm{pA} / \mathrm{pF}(n=5)$.

Similar experiments as shown in Figure $11 C$ were performed under current-clamp conditions. In a solution containing $2.5 \mathrm{~mm}$ $\mathrm{K}^{+}, 3 \mathrm{mM} \mathrm{Mg}^{2+}$, and no $\mathrm{Ca}^{2+}$, the resting potential was adjusted to $-40 \mathrm{mV}$ by injecting depolarizing current. After application of E-4031 $(5 \mu \mathrm{M})$, the membrane potential depolarized by $\sim 9 \mathrm{mV}$ $(9.3 \pm 1.5 ; n=6)$ to a steady-state value. Subsequent DHPG (50 $\mu \mathrm{M})$ application elicited a transient depolarization $(6.9 \pm 2.1 \mathrm{mV}$; $n=4$ ) on top of the E-4031-induced steady-state depolarization (data not shown). These experiments demonstrated that the DHPG-induced reduction of the erg outward current measured at $-40 \mathrm{mV}$ (Fig. 11) could be detected under current-clamp conditions as a depolarization. At the resting potential of $\sim-60 \mathrm{mV}$ and in the presence of physiological external $\mathrm{Ca}^{2+}$, the erg outward current is presumably smaller than at $-40 \mathrm{mV}$. Nevertheless, the on-cell recording of Figure 1 proves that at the resting potential a sufficient amount of erg current is activated to suppress Purkinje cell excitability. During the steady-state component of the DHPG response, cell excitability was increased (Fig. $11 E-G)$. In the absence of DHPG, a depolarizing $100 \mathrm{pA}$ current injection elicited an initial action potential followed by slow membrane potential oscillations. After application of DHPG (50 $\mu \mathrm{M})$ for $>200 \mathrm{~s}$, the same depolarizing current elicited repetitive activity, i.e., the threshold potential was significantly decreased. Subsequent application of E-4031 (5 $\mu \mathrm{M})$ in the continued presence of DHPG did not induce a further significant change in the threshold potential (control threshold potential: $-38.7 \pm 0.9$ $\mathrm{mV}$; in the presence of DHPG: $-41.7 \pm 0.4 \mathrm{mV} ; n=5 ; p=0.017$; in the presence of DHPG plus E-4031: $-42.9 \pm 0.6 ; n=6 ; p=$ $0.130, t$ test). In the presence of TTX, we investigated whether DHPG had changed the input resistance. From the membrane potential change induced by a $100 \mathrm{pA}$ depolarizing current, we found that the input resistance significantly increased in the pres- 
A DHPG

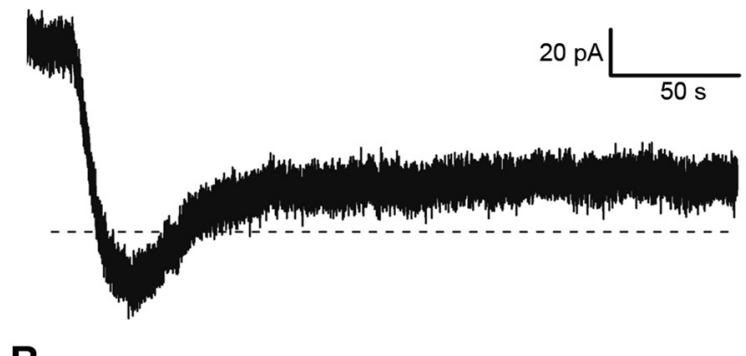

B
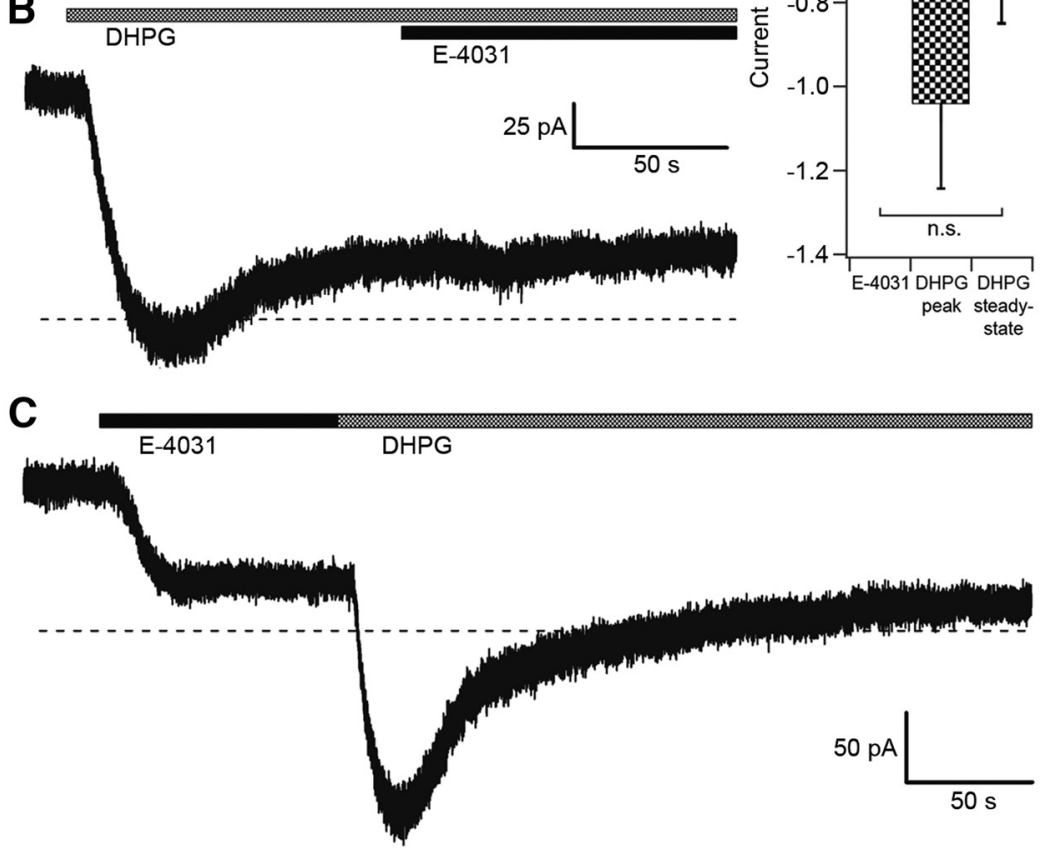

E

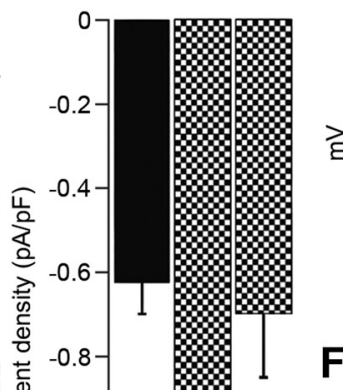

E control

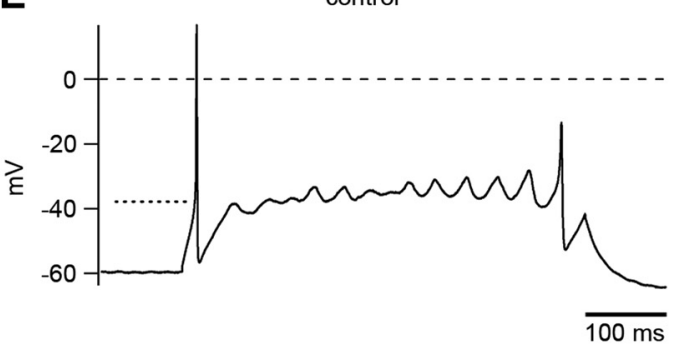

$\mathbf{F}$

DHPG

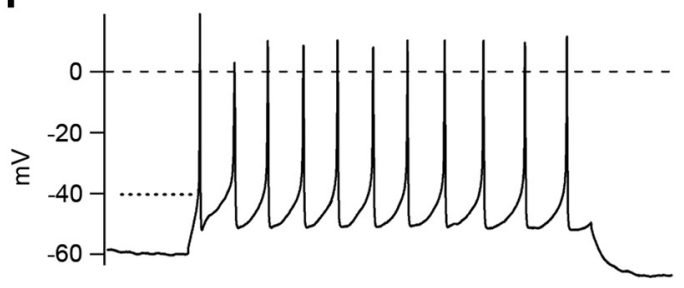

\section{G}

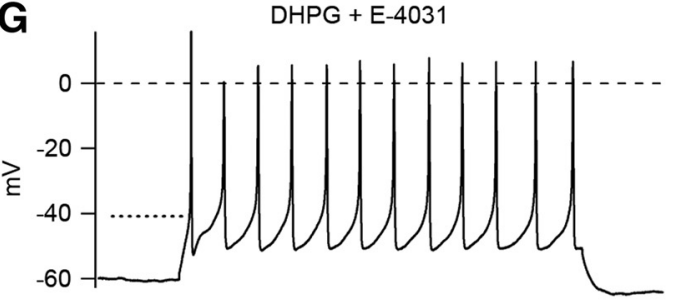

Figure 11. Erg current contributes to the DHPG-induced biphasic current response. $\boldsymbol{A}-\boldsymbol{D}$, Purkinje cells were voltage-clamped at $-40 \mathrm{mV}$. External solution, $5 \mathrm{~mm} \mathrm{~K}{ }^{+}$without $\mathrm{Ca}^{2+} . \boldsymbol{A}$, Application of DHPG (50 $\mu \mathrm{m}$, gray bar) induced a biphasic current response. B, Application of E-4031 $(5 \mu \mathrm{M})$ during the sustained current component (black bar) did not change the current. $C$, Application of E-4031 decreased a sustained outward current. Subsequent application of DHPG induced a transient current only. $D$, Mean amplitudes of the E-4031-sensitive current (black column; $n=13$ ), the peak amplitude of the transient, and the sustained current DHPG-sensitive component (black-and-white columns; $n=5$; n.s., not significant; unpaired 2-tailed $t$ test). $\boldsymbol{E}$ - $\boldsymbol{G}$, Current-clamp recordings during the steady-state component of the DHPG response and $\sim 200$ s after DHPG ( $50 \mu \mathrm{m})$ application. In the presence of DHPG, a depolarizing current injection ( $500 \mathrm{ms,}$ $100 \mathrm{pA}$ ) from a membrane potential of $-60 \mathrm{mV}$ decreased the threshold potential and induced repetitive activity. Additional application of E-4031 (5 $\mu \mathrm{m})$ induced no further significant change in threshold potential and repetitive activity. The dotted line near $-40 \mathrm{mV}$ indicates the threshold potential determined with the phase plane plot.

ence of DHPG (control: $168 \pm 12 \mathrm{M} \Omega$; DHPG: $192 \pm 12 \mathrm{M} \Omega$; $n=5 ; p<0.02$ ). Subsequent application of E-4031 in the presence of DHPG increased the input resistance still further (220 $\mathrm{M} \Omega$; see above).

\section{Discussion}

Purkinje cells of neonatal mice (P5-P10) contain a subthreshold current that is mediated by erg channels. Its blockage by E-4031 decreases the threshold potential and increases the frequency of action potential firing. The biophysical properties of the native erg currents resemble those mediated by erg1/erg3 channels. The importance of erg channels with fast gating kinetics like erg3 was corroborated by the results of action potential clamp experiments and computer simulation. Activation of mGluR1 by DHPG inhibits the native erg current, thereby decreasing the threshold potential and increasing Purkinje cell excitability.

The functional importance of fast erg channels in Purkinje cells of neonatal mice

Erg1, erg2, and erg3 are differentially expressed throughout the rat and mouse brain (Saganich et al., 2001; Papa et al., 2003;
Guasti et al., 2005). The two isoforms of erg1 (erg1a and erg1b), as well as erg2 and erg3 channel subunits, are expressed in Purkinje cells and deep nuclei of the mouse cerebellum, whereas in the other parts of the cerebellum erg channel abundance is low (Guasti et al., 2005). All erg subunits are present in Purkinje cells at the protein level (Guasti et al., 2005; Hagendorf et al., 2009). The qPCR data show that in the cerebellum of neonatal mice (Table 4) the transcript abundance decreases in the following order: $\operatorname{erg} 1 \mathrm{a}>\operatorname{erg} 2>\operatorname{erg} 3>\operatorname{erg} 1 \mathrm{~b}$.

Both, the scorpion toxin BeKm-1 and the sea anemone toxin APETx1 blocked the native erg current to a degree similar to heterologously expressed erg 1 channels and erg1/erg3 concatemers. Together with the high mRNA abundance of ergla in the cerebellum, these results suggest that the erg channels in Purkinje cells of neonatal mice are predominantly composed of erg1 channel subunits. But homomeric erg1 channels cannot explain the biophysical properties of the erg channels in Purkinje cells of neonatal mice (Table 3), and it cannot explain the absence of accommodation. Native erg channels are activated between -60 and $-40 \mathrm{mV}$, i.e., within a potential range where erg1a, erg1b, and erg2 channels are closed. A likely explanation is that erg 
channels in Purkinje cells correspond to heteromeric erg1/erg3 channels. Heteromeric erg channels acquire new biophysical properties if compared with homomeric erg channels, e.g., erg1/ erg3 channels display faster gating kinetics and activate at more negative potentials than homomeric ergla channels (Wimmers et al., 2001, 2002). In the light of these observations, the data of Table 3 support the possible functional importance of erg3 channel subunits for the formation of erg channels in Purkinje cells of neonatal mice. Alternatively, Purkinje cell erg channels consist of erg1 channels, whose biophysical properties are modified by assembly with ancillary subunits (Pongs and Schwarz, 2010) or by other as yet unknown mechanisms.

The contribution of erg 3 channel subunits to the formation of native erg channels could explain the absence of accommodation in neonatal Purkinje cells. It could also explain the shift in the threshold potential of Purkinje cells to more depolarized potentials, the increase of first spike-latency and the decrease in the frequency of repetitive activity. Experiments using action potential clamp activated a small subthreshold erg current of $\sim 40 \mathrm{pA}$, which effectively slowed repetitive activity (Fig. 3). In HEK 293 cells expressing erg 3 channels, an erg current of a similar relative amplitude was elicited with the same action potential clamp pulses, whereas the other erg subunits exhibited much smaller current amplitudes. Incorporation of erg3 channel conductance in the Purkinje cell computer model faithfully simulated the proposed functional role of an erg current in which erg3 channel subunits would be involved. In addition, the decrease in mRNA abundance of erg 3 channel subunits by $50 \%$ during development supports their functional importance for neonatal erg channels. Presumably, as a consequence of this, Purkinje cells of adult mice exhibit pronounced accommodation during repetitive activity (Sacco et al., 2003).

Although the transcript abundance of erg2 subunits is relatively high, the biophysical properties of erg2 channels (activation curve shifted to depolarized potentials, slow gating kinetics) are so different from those of native erg currents that it is unlikely that they contribute to erg channels activated near subthreshold potentials. This notion is also supported by the experiments with BeKm-1 (see above). Interestingly, immunocytochemistry showed that erg2 proteins are not only present in the soma but also in the proximal dendrites, whereas erg1a and erg3 proteins are confined to the Purkinje cell soma (Guasti et al., 2005; Hagendorf et al., 2009). However, it is not known which function erg2 channels fulfill in the proximal dendrites. This is also true for erg $1 \mathrm{~b}$ channels. Since their relative expression in the cerebellum is low and their biophysical properties are so different from those of native erg channels (shift of activation curve to depolarized potentials), erg $1 \mathrm{~b}$ channels may not play an important role for the formation of neuronal subthreshold erg channels. This is in contrast to the heart, where erg2 and erg3 subunits are not expressed, and the concentration of erg $1 \mathrm{~b}$ transcripts relative to ergla is higher than in the cerebellum $(10-20 \%)$. Therefore, erg1b and ergla subunits assemble to form cardiac erg channels (Jones et al., 2004; Larsen et al., 2008; Jonsson et al., 2012). In contrast to neuronal erg currents, cardiac erg $1 \mathrm{a} / \operatorname{erg} 1 \mathrm{~b}$ currents fulfill a clear suprathreshold function, i.e., they help to repolarize the heart action potential (Sanguinetti and Tristani-Firouzi, 2006).

The increase in threshold potential upon erg channel opening is induced by the increase in outward $\mathrm{K}^{+}$current opposing the $\mathrm{Na}$ inward current in the soma membrane as well as by the slight decrease in input resistance. In Purkinje cells, the action potential is generated in the distal part of the axon initial segment (AIS) because in the AIS the threshold potential is very low (Foust et al., 2010; Palmer et al., 2010). Since soma and AIS are strongly electrotonically coupled, the threshold potential in the AIS will be influenced by electrotonic spread of the soma depolarization to the AIS, similar to the electrotonic spread of the synaptic potentials to the AIS. Future experiments will need to investigate the hypothesis that activation of erg outward $\mathrm{K}^{+}$current delays the electrotonic spread of soma depolarization to the AIS leading to partial inactivation of $\mathrm{Na}$ channels in the AIS, and thereby increasing the threshold potential.

\section{Modulation of erg currents}

Neuronal excitability can be modulated by a change in erg channel expression during development (Furlan et al., 2005; Hardman and Forsythe, 2009) or upon sensory stimulation (Hagendorf et al., 2009). Another possibility to change excitability is the inhibition of erg currents by activation of G-protein-coupled receptors. Erg currents are inhibited in mitral cells of the olfactory bulb by the mGluR1 activator DHPG (Hirdes et al., 2009), in lactotropes by thyrotropin-releasing hormone (Bauer et al., 1990), and in gonadotropes by gonadotropin-releasing hormone (Hirdes et al., 2010). We show here that mGluR1 activation by DHPG effectively inhibits the erg current in Purkinje cells. The reduction of the maximal erg current amplitude by $\sim 50 \%$ and the shift of the activation curve to more positive membrane potentials by $\sim 10$ $\mathrm{mV}$ add up to an erg current inhibition of $\sim 70 \%$.

In Purkinje cells, activation of mGluR1 by DHPG induces a biphasic current response consisting of a transient and a sustained inward current (Yamakawa and Hirano, 1999; Hartmann and Konnerth, 2009). Whereas the transient inward current is mediated by TRPC3 channels (Hartmann et al., 2008), the sustained current could be mediated by an erg current, as shown by our experiments or, for example, by an $\mathrm{Ca}^{2+} / \mathrm{Na}^{+}$exchanger (Knöpfel et al., 2000). Activation of mGluR1 by DHPG induces a transient increase in the firing of action potentials due to the activation of a transient inward current through TRPC 3 channels as well as a subsequent sustained increase in action potential firing (Yamakawa and Hirano, 1999). At least part of this increase in cell excitability is due to the reduction of the erg current, which is sufficient to significantly decrease the threshold potential and to elicit repetitive activity (see Fig. 11). Future studies will clarify how mGluR1-induced erg channel inhibition may be involved in processes related to Purkinje cell plasticity, such as long-term depression.

\section{References}

Bauer CK, Meyerhof W, Schwarz JR (1990) An inward-rectifying K+ current in clonal rat pituitary cells and its modulation by thyrotrophinreleasing hormone. J Physiol 429:169-189. Medline

Bean BP (2007) The action potential in mammalian central neurons. Nat Rev Neurosci 8:451-465. CrossRef Medline

Boda E, Pini A, Hoxha E, Parolisi R, Tempia F (2009) Selection of reference genes for quantitative real-time RT-PCR studies in mouse brain. J Mol Neurosci 37:238-253. CrossRef Medline

Curran ME, Splawski I, Timothy KW, Vincent GM, Green ED, Keating MT (1995) A molecular basis for cardiac arrhythmia: HERG mutations cause long QT syndrome. Cell 80:795-803. CrossRef Medline

Diochot S, Loret E, Bruhn T, Béress L, Lazdunski M (2003) APETx1, a new toxin from the sea anemone Anthopleura elegantissima, blocks voltagegated human ether-a-go-go-related gene potassium channels. Mol Pharmacol 64:59-69. CrossRef Medline

Foust A, Popovic M, Zecevic D, McCormick DA (2010) Action potentials initiate in the axon initial segment and propagate through axon collaterals reliably in cerebellar Purkinje neurons. J Neurosci 30:6891-6902. CrossRef Medline

Furlan F, Guasti L, Avossa D, Becchetti A, Cilia E, Ballerini L, Arcangeli A 
(2005) Interneurons transiently express the ERG K+ channels during development of mouse spinal networks in vitro. Neuroscience 135:11791192. CrossRef Medline

Furlan F, Taccola G, Grandolfo M, Guasti L, Arcangeli A, Nistri A, Ballerini L (2007) ERG conductance expression modulates the excitability of ventral horn GABAergic interneurons that control rhythmic oscillations in the developing mouse spinal cord. J Neurosci 27:919-928. CrossRef Medline

Guasti L, Cilia E, Crociani O, Hofmann G, Polvani S, Becchetti A, Wanke E, Tempia F, Arcangeli A (2005) Expression pattern of the ether-a-go-gorelated (ERG) family proteins in the adult mouse central nervous system: evidence for coassembly of different subunits. J Comp Neurol 491:157174. CrossRef Medline

Hagendorf S, Fluegge D, Engelhardt C, Spehr M (2009) Homeostatic control of sensory output in basal vomeronasal neurons: activity-dependent expression of ether-a-go-go-related gene potassium channels. J Neurosci 29:206-221. CrossRef Medline

Hardman RM, Forsythe ID (2009) Ether-a-go-go-related gene K+ channels contribute to threshold excitability of mouse auditory brainstem neurons. J Physiol 587:2487-2497. CrossRef Medline

Hartmann J, Konnerth A (2009) Mechanisms of metabotropic glutamate receptor-mediated synaptic signaling in cerebellar Purkinje cells. Acta Physiol (Oxf) 195:79-90. CrossRef Medline

Hartmann J, Dragicevic E, Adelsberger H, Henning HA, Sumser M, Abramowitz J, Blum R, Dietrich A, Freichel M, Flockerzi V, Birnbaumer L, Konnerth A (2008) TRPC3 channels are required for synaptic transmission and motor coordination. Neuron 59:392-398. CrossRef Medline

Hines ML, Carnevale NT (1997) The NEURON simulation environment. Neural Comput 9:1179-1209. CrossRef Medline

Hirdes W, Schweizer M, Schuricht KS, Guddat SS, Wulfsen I, Bauer CK, Schwarz JR (2005) Fast erg K+ currents in rat embryonic serotonergic neurones. J Physiol 564:33-49. CrossRef Medline

Hirdes W, Napp N, Wulfsen I, Schweizer M, Schwarz JR, Bauer CK (2009) Erg $\mathrm{K}+$ currents modulate excitability in mouse mitral/tufted neurons. Pflugers Arch 459:55-70. CrossRef Medline

Hirdes W, Dinu C, Bauer CK, Boehm U, Schwarz JR (2010) Gonadotropinreleasing hormone inhibits ether-a-go-go-related gene $\mathrm{K}+$ currents in mouse gonadotropes. Endocrinology 151:1079-1088. CrossRef Medline

Hodgkin AL, Huxley AF (1952) A quantitative description of membrane current and its application to conduction and excitation in nerve. J Physiol 117:500-544. Medline

Ito M (2006) Cerebellar circuitry as a neuronal machine. Prog Neurobiol 78:272-303. Medline

Jackson AC, Bean BP (2007) State-dependent enhancement of subthreshold A-type potassium current by 4 -aminopyridine in tuberomammillary nucleus neurons. J Neurosci 27:10785-10796. CrossRef Medline

Jones EM, Roti Roti EC, Wang J, Delfosse SA, Robertson GA (2004) Cardiac IKr channels minimally comprise hERG $1 \mathrm{a}$ and $1 \mathrm{~b}$ subunits. J Biol Chem 279:44690-44694. CrossRef Medline

Jonsson MK, van der Heyden MA, van Veen TA (2012) Deciphering hERG channels: molecular basis of the rapid component of the delayed rectifier potassium current. J Mol Cell Cardiol 53:369-374. CrossRef Medline

Khaliq ZM, Gouwens NW, Raman IM (2003) The contribution of resurgent sodium current to high-frequency firing in Purkinje neurons: an experimental and modeling study. J Neurosci 23:4899-4912. Medline

Knöpfel T, Anchisi D, Alojado ME, Tempia F, Strata P (2000) Elevation of intradendritic sodium concentration mediated by synaptic activation of metabotropic glutamate receptors in cerebellar Purkinje cells. Eur J Neurosci 12:2199-2204. CrossRef Medline

Korolkova YV, Kozlov SA, Lipkin AV, Pluzhnikov KA, Hadley JK, Filippov AK, Brown DA, Angelo K, Strøbaek D, Jespersen T, Olesen SP, Jensen BS, Grishin EV (2001) An ERG channel inhibitor from the scorpion Buthus eupeus. J Biol Chem 276:9868-9876. CrossRef Medline

Kupershmidt S, Snyders DJ, Raes A, Roden DM (1998) A K+ channel splice variant common in human heart lacks a C-terminal domain required for expression of rapidly activating delayed rectifier current. J Biol Chem 273:27231-27235. CrossRef Medline
Larsen AP, Olesen SP (2010) Differential expression of hERG1 channel isoforms reproduces properties of native I $(\mathrm{Kr})$ and modulates cardiac action potential characteristics. PloS One 5:e9021. CrossRef Medline

Larsen AP, Olesen SP, Grunnet M, Jespersen T (2008) Characterization of hERG1a and hERG1b potassium channels-a possible role for hERG1b in the I (Kr) current. Pflugers Arch 456:1137-1148. CrossRef Medline

Llinás R, Walton KD, Lang EJ (2004) Cerebellum. In: The synaptic organization of the brain, 5th edition (Shepher GM, ed), pp 271-309. New York: Oxford UP

Palmer LM, Clark BA, Gründemann J, Roth A, Stuart GJ, Häusser M (2010) Initiation of simple and complex spikes in cerebellar Purkinje cells. J Physiol 588:1709-1717. CrossRef Medline

Papa M, Boscia F, Canitano A, Castaldo P, Sellitti S, Annunziato L, Taglialatela M (2003) Expression pattern of the ether-a-gogo-related (ERG) K+ channel-encoding genes ERG1, ERG2, and ERG3 in the adult rat central nervous system. J Comp Neurol 466:119-135. CrossRef Medline

Pessia M, Servettini I, Panichi R, Guasti L, Grassi S, Arcangeli A, Wanke E, Pettorossi VE (2008) ERG voltage-gated K+ channels regulate excitability and discharge dynamics of the medial vestibular nucleus neurones. J Physiol 586:4877-4890. CrossRef Medline

Pongs O, Schwarz JR (2010) Ancillary subunits associated with voltagedependent K+ channels. Physiol Rev 90:755-796. CrossRef Medline

Raman IM, Bean BP (1999) Ionic currents underlying spontaneous action potentials in isolated cerebellar Purkinje neurons. J Neurosci 19:16631674. Medline

Restano-Cassulini R, Korolkova YV, Diochot S, Gurrola G, Guasti L, Possani LD, Lazdunski M, Grishin EV, Arcangeli A, Wanke E (2006) Species diversity and peptide toxins blocking selectivity of ether-a-go-go-related gene subfamily $\mathrm{K}+$ channels in the central nervous system. Mol Pharmacol 69:1673-1683. CrossRef Medline

Sacco T, Bruno A, Wanke E, Tempia F (2003) Functional roles of an ERG current isolated in cerebellar Purkinje neurons. J Neurophysiol 90:18171828. CrossRef Medline

Saganich MJ, Machado E, Rudy B (2001) Differential expression of genes encoding subthreshold-operating voltage-gated $\mathrm{K}+$ channels in brain. J Neurosci 21:4609-4624. Medline

Sanguinetti MC, Tristani-Firouzi M (2006) hERG potassium channels and cardiac arrhythmia. Nature 440:463-469. CrossRef Medline

Schönherr R, Rosati B, Hehl S, Rao VG, Arcangeli A, Olivotto M, Heinemann SH, Wanke E (1999) Functional role of the slow activation property of ERG K+ channels. Eur J Neurosci 11:753-760. CrossRef Medline

Shi W, Wymore RS, Wang HS, Pan Z, Cohen IS, McKinnon D, Dixon JE (1997) Identification of two nervous system-specific members of the erg potassium channel gene family. J Neurosci 17:9423-9432. Medline

Shibasaki T (1987) Conductance and kinetics of delayed rectifier potassium channels in nodal cells of the rabbit heart. J Physiol 387:227-250. Medline

Sturm P, Wimmers S, Schwarz JR, Bauer CK (2005) Extracellular potassium effects are conserved within the rat erg $\mathrm{K}+$ channel family. J Physiol 564:329-345. CrossRef Medline

Wang S, Liu S, Morales MJ, Strauss HC, Rasmusson RL (1997) A quantitative analysis of the activation and inactivation kinetics of HERG expressed in Xenopus oocytes. J Physiol 502:45-60. CrossRef Medline

Weinsberg F, Bauer CK, Schwarz JR (1997) The class III antiarrhythmic agent E-4031 selectively blocks the inactivating inward-rectifying potassium current in rat anterior pituitary tumor cells (GH3/B6 cells). Pflugers Arch 434:1-10. CrossRef Medline

Wimmers S, Wulfsen I, Bauer CK, Schwarz JR (2001) Erg1, erg2 and erg3 K channel subunits are able to form heteromultimers. Pflugers Arch 441: 450-455. CrossRef Medline

Wimmers S, Bauer CK, Schwarz JR (2002) Biophysical properties of heteromultimeric erg K+ channels. Pflugers Arch 445:423-430. CrossRef Medline

Yamakawa Y, Hirano T (1999) Contribution of mGluR1 to the basal activity of a mouse cerebellar Purkinje neuron. Neurosci Lett 277:103-106. CrossRef Medline 